This document is the accepted manuscript version of the following article:

Stewart, L., Alsos, I. G., Bay, C., Breen, A. L., Brochmann, C., Boulanger-Lapointe, N., ... Pellissier, L. (2016). The regional species richness and genetic diversity of Arctic vegetation reflect both past glaciations and current climate. Global Ecology and

Biogeography, 25(4), 430-442. https://doi.org/10.1111/geb.12424

\title{
The regional species richness and genetic diversity of arctic vegetation reflect both past glaciations and current climate
}

Lærke Stewart ${ }^{1,2,3}$, Inger G. Alsos ${ }^{4}$, Christian Bay ${ }^{1}$, Amy L. Breen ${ }^{5,6}$, Christian Brochmann ${ }^{7}$, Noémie Boulanger-Lapointe ${ }^{8}$, Olivier Broennimann ${ }^{9}$, Helga Bültmann ${ }^{10}$, Peder Klith Bøcher ${ }^{11}$, Christian Damgaard ${ }^{12}$, Fred J. A. Daniëls ${ }^{10}$, Dorothee Ehrich ${ }^{13}$, Pernille Bronken Eidesen ${ }^{14}$, Antoine Guisan $^{9,15}$, Ingibjörg Svala Jónsdóttir ${ }^{14,16}$, Jonathan Lenoir ${ }^{17}$, Peter C. le Roux ${ }^{18,19}$, Esther Lévesque $^{20}$, Miska Luoto ${ }^{18}$, Jacob Nabe-Nielsen ${ }^{1,2}$, Peter Schönswetter ${ }^{21}$, Andreas Tribsch ${ }^{22}$, Liv Unn Tveraabak $^{23}$, Risto Virtanen ${ }^{24}$, Donald A. Walker ${ }^{25}$, Kristine B. Westergaard ${ }^{4,26}$, Nigel G. Yoccoz $^{13}$, Jens-Christian Svenning ${ }^{11 \dagger}$, Mary Wisz ${ }^{1,2,3,27 \dagger}$, Niels Martin Schmidt ${ }^{1,2 \dagger}$, Loïc Pellissier ${ }^{28 \dagger}$

\section{${ }^{\dagger}$ Shared last authorship}

${ }^{1}$ Department of Bioscience, Aarhus University, Frederiksborgvej 399, 4000 Roskilde, Denmark,

${ }^{2}$ Arctic Research Centre, Aarhus University, 8000 Aarhus, Denmark, ${ }^{3}$ Greenland Climatic Research Centre, Greenland Institute of Natural Resources, 3900 Nuuk, Greenland, ${ }^{4}$ Tromsø University Museum, NO-9037 Tromsø, Norway, ${ }^{5}$ International Arctic Research Center, University of Alaska Fairbanks, ${ }^{6}$ Alaska Geobotany Center, Institute of Arctic Biology, University of Alaska Fairbanks, ${ }^{7}$ National Centre for Biosystematics, Natural History Museum, University of Oslo, NO-0318 Oslo, Norway, ${ }^{8}$ Department of Geography, University of British Columbia, 1984 West Mall, Vancouver, BC Canada V6T 1Z2, ${ }^{9}$ Department of Ecology and Evolution, University of Lausanne, Biophore, 1015 Lausanne, Switzerland, ${ }^{10}$ Institute of Biology and Biotechnology of Plants, University of Münster, 48143 Münster, Germany, ${ }^{11}$ Department of Bioscience, Aarhus University, Ny Munkegade 116, 8000 Aarhus, Denmark, ${ }^{12}$ Department of Bioscience, Aarhus University, Vejlsøvej 25, 8600 Silkeborg, Denmark, ${ }^{13}$ Department of Arctic and Marine Biology, UiT - The Arctic University of Norway, NO-9037 Tromsø, Norway, ${ }^{14}$ The University Centre in Svalbard, PO Box 156, NO-9171, Longyearbyen, Norway, ${ }^{15}$ Institute of Earth Surface Dynamics, University of Lausanne, Geopolis, 1015 Lausanne, Switzerland, ${ }^{16}$ University of Iceland, Faculty of Life- and Environmental Sciences, Askja, Sturlugata 7, 101 Reykjavík, Iceland, ${ }^{17}$ Unité de Recherche "Ecologie et Dynamique des Systèmes Anthropisés" (EDYSAN, FRE 3498 CNRS-UPJV), Université de Picardie Jules Verne, 1 rue des Louvels, F-80037 Amiens Cedex, France, ${ }^{18}$ Department of Geosciences and Geography P.O. Box 64, Gustaf Hällströmin katu 2, 00014 University of Helsinki, Finland, ${ }^{19}$ Department of Plant Science, University of Pretoria, Private bag X20 Hatfield, Pretoria 0028, South Africa, ${ }^{20}$ Université du Québec à Trois-Rivières, 500 TroisRivières, Qc, Canada, ${ }^{21}$ University of Innsbruck, Institute of Botany, A-6020 Innsbruck, Austria, ${ }^{22}$ University of Salzburg, Department of Organismic Biology, A-5020 Salzburg, Austria, ${ }^{23}$ Høgskolen i Nesna, Seksjon for Naturfag, 8700 Nesna, Norge, ${ }^{24}$ Department of Biology, P.O. Box 8000 FI-90014 University of Oulu, Oulu, Finland, ${ }^{25}$ Department of Biology and Wildlife, Institute of Arctic Biology, University of Alaska Fairbanks, Fairbanks, AK USA 99709, ${ }^{26}$ Norwegian 
Institute for Nature Research, NO-7485 Trondheim, Norway, ${ }^{27}$ Department of Ecology and Environment, DHI, Agern Allé 5, 2970 Hørsholm, Denmark, ${ }^{28}$ Université de Fribourg, Unit of Ecology and Evolution 1700 Fribourg, Switzerland.

\section{Emails}

LS (lst@bios.au.dk), IGA (inger.g.alsos@uit.no), CB (cba@bios.au.dk), ALB (albreen@alaska.edu), CB (christian.brochmann@nhm.uio.no), NBL (noemie.boulangerlapointe@geog.ubc.ca), OB(olivier.broennimann@unil.ch), HB (bultman@uni-muenster.de), PKB (peder.bocher@bios.au.dk),CD (cfd@bios.au.dk),FJAD (daniels@uni-muenster.de),DE (dorothee.ehrich@uit.no), PBE (pernillee@unis.no), AG (antoine.guisan@unil.ch), ISJ (isj@hi.is), JL (jonathan.lenoir@u-picardie.fr), PCIR (peter.leroux@up.ac.za),EL (Esther.Levesque@uqtr.ca), ML (msluoto@mappi.helsinki.fi),.JNN (jnn@bios.au.dk), PS (Peter.Schoenswetter@uibk.ac.at), AT (andreas.tribsch@sbg.ac.at), LUT (ut@hinesna.no), RV (risto.virtanen@oulu.fi), DAW (dawalker@alaska.edu), KBW (Kristine.westergaard@nina.no), NGY (nigel.yoccoz@uit.no),.JCS (svenning@bios.au.dk), MSW (msw@dhigroup.com), NMS (nms@bios.au.dk),.PP (loic.pellissier@unifr.ch)

\section{Keywords}

Arctic plants, species richness, glaciation history, intra-specific genetic diversity, AFLP, taxonomic groups, vascular plants, bryophytes, lichens

\section{Short running-title}

Glaciation-effect on arctic vegetation diversity

\section{Corresponding author}

Loïc Pellissier, Department of Ecology and Evolution, Université de Fribourg, Chemin du Musée 10, CH-1700 Fribourg, Switzerland

E-mail: loic.pellissier@unifr.ch 


\section{ABSTRACT}

\section{Aim}

The Arctic has experienced marked climatic differences between glacials and interglacials and is now subject to a rapidly warming climate. Knowledge of the effects of historical processes on current diversity patterns may aid our predictions of vegetation responses to future climate change. We aim to test whether plant species and genetic diversity patterns are correlated with time since deglaciation at regional as well as local scales. We also investigate whether regional species richness patterns are correlated with genetic diversity in vascular plants.

\section{Location Circumarctic}

Methods We investigated species richness of the vascular plant flora of 21 floristic provinces and examined local species richness in 6215 vegetation plots distributed across the Arctic. We assessed levels of genetic diversity inferred from Amplified Fragment Length Polymorphism variation across populations of 23 common Arctic species. Correlations between diversity measures and landscape age (time since deglaciation) as well as variables characterising current climate were analysed using spatially explicit simultaneous autoregressive models.

Results Regional species richness of vascular plants and genetic diversity were correlated with each other, and both showed a positive relationship with landscape age. Plot species richness showed differing responses for vascular plants, bryophytes and lichens. At this finer scale, richness of vascular plants was not significantly related to landscape age, which had a small effect size compared to the models of bryophytes and lichens diversity.

Main conclusion Our study suggests that the imprint of past glaciations in arctic vegetation diversity patterns at the regional scale are still detectable today. Since arctic vegetation is still 
limited by postglacial migration lag, it will most probably also exhibit lags in response to current and future climate change. Our results also suggest that local species richness at the plot scale is more determined by local habitat factors. 


\section{INTRODUCTION}

The Arctic is warming twice as fast as any other region on Earth potentially triggering a range of ecological responses (Callaghan et al., 2005; CAFF, 2013). Shrubs are encroaching on sub-arctic habitats and some cold-adapted plant species have shifted their distributional ranges towards higher latitudes and elevation (Lenoir \& Svenning, 2013). Bounded to the north by the Arctic ocean, the surface available to the terrestrial Arctic ecosystem is shrinking globally as subarctic climates and habitats are moving north (Crawford et al., 2003; CAFF, 2013). This may ultimately cause extinction of species whose suitable habitat disappear (Thuiller et al., 2005). Because parts of species ranges are lost, climate change is expected to lead to loss of intraspecific genetic diversity (Alsos et al., 2012). Consequently this is expected to limit species' potentials for adaptive responses to climate change (Jump et al., 2009).

Understanding and forecasting the response of current biodiversity to on-going climate change can benefit from studying ecosystem responses to past climate changes (Sandel et al., 2011). In this context, a key aspect to consider is disequilibrium dynamics, since equilibrium conditions are often assumed when investigating the relationship between biodiversity and current climate (Araujo \& Pearson, 2005). This may lead to inaccurate forecasts of species distributional ranges if species show delayed responses to changing conditions, including for example migration lag ( Bertrand et al., 2011; Sandel et al., 2011) or extinction debt (Tilman et al., 1994). In the Arctic, Quaternary climatic fluctuations and associated displacement of the ice sheets have been substantial and frequent (Svendsen et al., 2004). Arctic biodiversity, including species richness and intraspecific genetic diversity, may therefore still be in disequilibrium with climate (Brubaker et al., 1995; Normand et al., 2013) which may influence the rate of response of biodiversity to future climate change (Svenning \& Sandel, 2013). 
During the Quaternary climatic fluctuations, conditions affecting the distribution of species changed, causing the spatial displacement of plant assemblages (Brubaker et al., 1995). Pollen records suggest strong shifts in vegetation structure between glacial and interglacial periods (de Vernal \& Hillaire-Marcel, 2008) with especially rapid advancement of shrub tundra during ice retreat as the climate became milder (Funder et al., 2001). Following the Last Glacial Maximum (LGM) plant species migrated from refugia to reach the distributional ranges that they currently occupy (Hultén, 1937; Abbott \& Brochmann, 2003). This recolonisation of the Arctic after the LGM occurred in several stages and the rapidity varied markedly among regions (Birks et al., 1994; Bennike et al., 1999; Kienast et al., 2011). Because of barriers to dispersal such as fjords, mountains and oceans, as well as the stochasticity of this recolonisation process, species may not have reached all currently suitable habitats but still be limited by dispersal (Hoffmann et al., 2010). On the other hand, the recurrent glacial cycles may have selected for a highly mobile flora able to track its potential niche through frequent long-distance dispersal events (Alsos et al., 2007; Brochmann et al., 2013).

The degree to which biodiversity was able to track the changing climate is expected to vary depending on the dispersal abilities of species (Lenoir et al., 2012). Because species generally show phylogenetic trait conservatism (Ackerly, 2009), taxonomic groups of closely related species may show comparable dispersal abilities. Similarly, functional traits may strongly vary across distantly related taxonomic groups with contrasting life histories. Arctic plant communities are largely dominated by three groups of primary producers: vascular plants, bryophytes and terricolous lichens. Compared to vascular plants, bryophytes and lichens have small spores or asexually produced diaspores which are light enough to be wind-dispersed, thus favouring long-distance dispersal (Munoz et al., 2004). Also, lichens and bryophytes can tolerate harsher climatic conditions 
(Kappen, 1993) and should therefore not need to travel as far as vascular plants in response to glaciation. This means that they would have shorter distances to disperse into ice-free areas following deglaciation. As a consequence, we hypothesise a differential effect of the time since ice retreat on the survival and thereby distribution of these three taxonomic groups.

The glacial-interglacial cycles have also left imprints on the current spatial structure of intraspecific (i.e. within species) genetic diversity in arctic species (Brochmann et al., 2003; Eidesen et al., 2013). The most obvious signature of historic range expansions is reduced genetic diversity in the populations inhabiting more recently colonized areas due to founder effects (Excoffier et al., 2009). In contrast, areas that have not recently been covered by ice and with less fluctuation in climatic change since the LGM have preserved higher genetic diversity in populations (Eidesen et al., 2013; Yannic et al., 2014). As species richness and genetic diversity have been expected to be shaped by the same historical processes (Vellend \& Geber, 2005), they have been hypothesised to co-vary (Vellend, 2005; Vellend \& Geber, 2005). Several studies have investigated this predicted relationship and while a number of them have found a relationship (He et al., 2008; Adams \& Vellend, 2011) others reported no correlations between these two measures of diversity (Puscas et al., 2008; Taberlet et al., 2012). It is generally believed that species diversity is determined by different processes at different spatial scales (Crawley \& Harral, 2001; Willis \& Whittaker, 2002). In their review, Willis and Whittaker (2002) agued that at the broadest spatial scales, the distribution of species is driven by historical processes acting over thousands to millions of years, while at local scales species richness is rather influenced by fine-scale biotic and abiotic interactions such as competition, habitat structure and availability. We therefore hypothesise a stronger effect of landscape age on regional than on local species richness.

Eidesen et al. (2013) showed that genetic diversity in Arctic plants matches glaciation history of the Pleistocene, but the extent to which it co-varies with current patterns of species richness is 
still unknown. By combining data on regional species richness as well as a unique vegetation plot database (with 6215 vegetation plots) with data on genetic diversity of populations for 23 northern plant species across the entire circumpolar region, we will address the following questions:

1. How does local (plot) and regional species richness relate to the age of arctic landscapes (number of years since ice retreat after the LGM)?

2. How do vascular plants, bryophytes and lichens differ in their responses to time since deglaciation?

3. Are patterns of species richness correlated with patterns of genetic diversity, indicating that they have been shaped by similar historical processes?

\section{MATERIALS AND METHODS}

\section{Species richness}

As a measure of regional-scale species richness we used data on vascular plants from the Panarctic Flora (PAF; http://nhm2.uio.no/paf) (Elven et al., 2011). This gives a measure of diversity within 21 subregions of the Arctic as defined by the Circumpolar Arctic Vegetation Map (CAVM, Appendix S1 in Supportin information) (CAVM Team, 2003; Walker et al., 2005). Studies of arctic biodiversity at the local scale rarely span the entire arctic region mostly because the circumpolar region is composed of many different countries with different scientific methodologies and traditions. Data of plant relevés were compiled from existing sources and spanned all circumpolar countries including Canada, USA (Alaska), Greenland, Iceland, Norway, Russia and Finland (for references of all data sets see Appendix S2). Most plots included were from the Arctic as defined by the CAVM (CAVM Team, 2003; Walker et al., 2005). Furthermore, plots from the northern part of Scandinavia (Norway and Finland) were included. We compiled georeferenced plots for which lists 


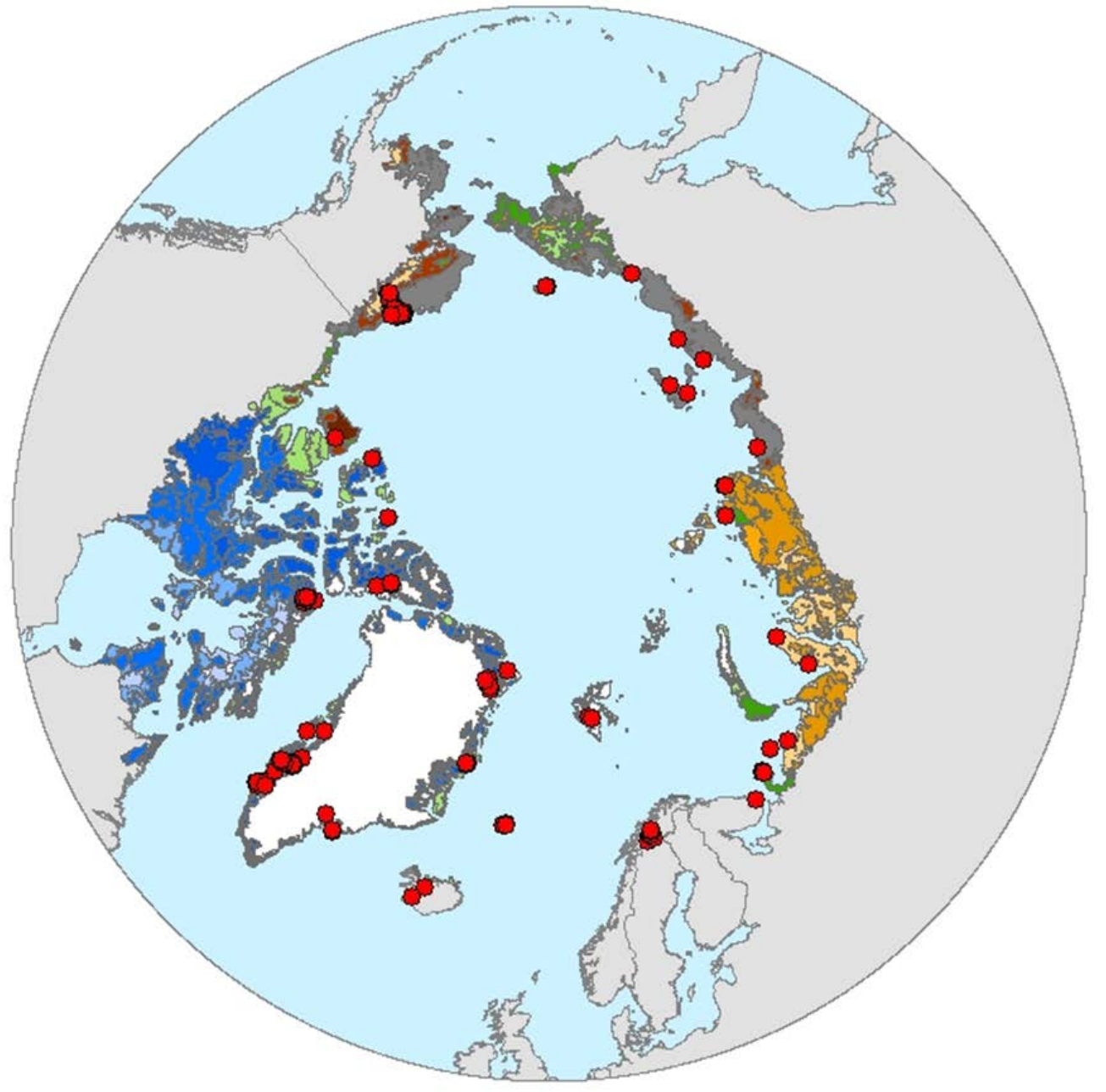

\section{Landscape age (1000s of years ago)}

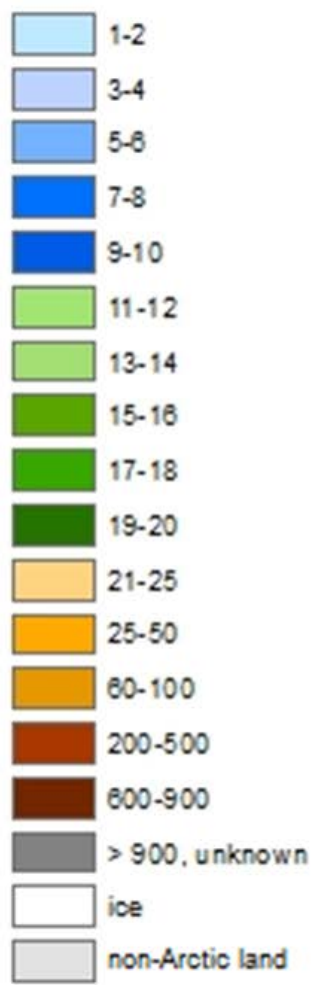

Figure 1. Map of time since ice retreat since the Last Glacial Maximum (LGM) across the Arctic. Modified from Raynolds and Walker (2009) where landscape age was constructed based on information on most recent deglaciation, emergence from sea, or drainage of proglacial lakes. The 1000 year time steps used in the SAR models have here been merged two and two to make a clearer presentation. Landscape ages older than 21,000 years were compiled in the category $>21$. Turquoise dots show the distribution of vegetation plots collected. One dot may indicate several vegetation plots at this location. The projection used is North_Pole_Lambert_Azimuthal_Equal_Area_180. The insert shows the number of plots sampled in each age category. The 828 plots sampled in ice were not covered in ice but sampled so close to permanent ice cover that the resolution of the map is not fine enough to display their true category. When analysed in the SAR models these plots were given the age 0 since it is assumed that these areas emerged from ice more recently than all other areas. 
of vascular plants, terricollous bryophytes and lichens had been recorded. For each plot we computed the total number of species for each of the three taxonomic groups. In total, we compiled data from 6215 vegetation plots distributed around the Arctic (Fig. 1) and with a mean plot size of $4.22 \mathrm{~m}^{2}\left(\mathrm{SD}=18.00 \mathrm{~m}^{2}\right)$.

\section{Genetic diversity}

We compiled data on vascular plant species from published work (Alsos et al., 2012, references to data sets on genetic diversity are given in Appendix S2), choosing species occurring in the Arctic bioclimatic zone at the treeline and beyond and leaving out species with very restricted ranges. This left 23 plant species (including 16 of the 17 analysed by Eidesen et al., 2013) for which we analysed the intraspecific genetic datasets. These datasets were constructed by genotyping 9416 individual plants from 1362 local populations using Amplified Fragment Length Polymorphisms (AFLPs) (78-334 markers per species). Within a local population, leaves from 11 individuals were collected $25 \mathrm{~m}$ apart along a line transect as in Eidesen et al., (2013). To create genetic diversity maps we transformed the estimates of diversity (D, estimated as the average proportion of pairwise differences between individual AFLP profiles) in order to enable the comparison between species following the formula: transformed value $=($ value $) /($ MAX value $)$. The full details of data collection and genetic structuring has been published elsewhere (Alsos et al., 2012). For each species the transformed genetic diversity was assigned to the grid cells where samples were available. Grid cell size of $50 \mathrm{~km}$ was chosen because this scale is small enough to separate the genetic groups into different areas, but still large enough to obtain large scale diversity patterns (Eidesen et al. 2013). The genetic diversity was then spatially interpolated to fill the unsampled grid cells within the outlined distribution range of each species using the rgdal package (Keitt et al., 2013) in R (Team, 


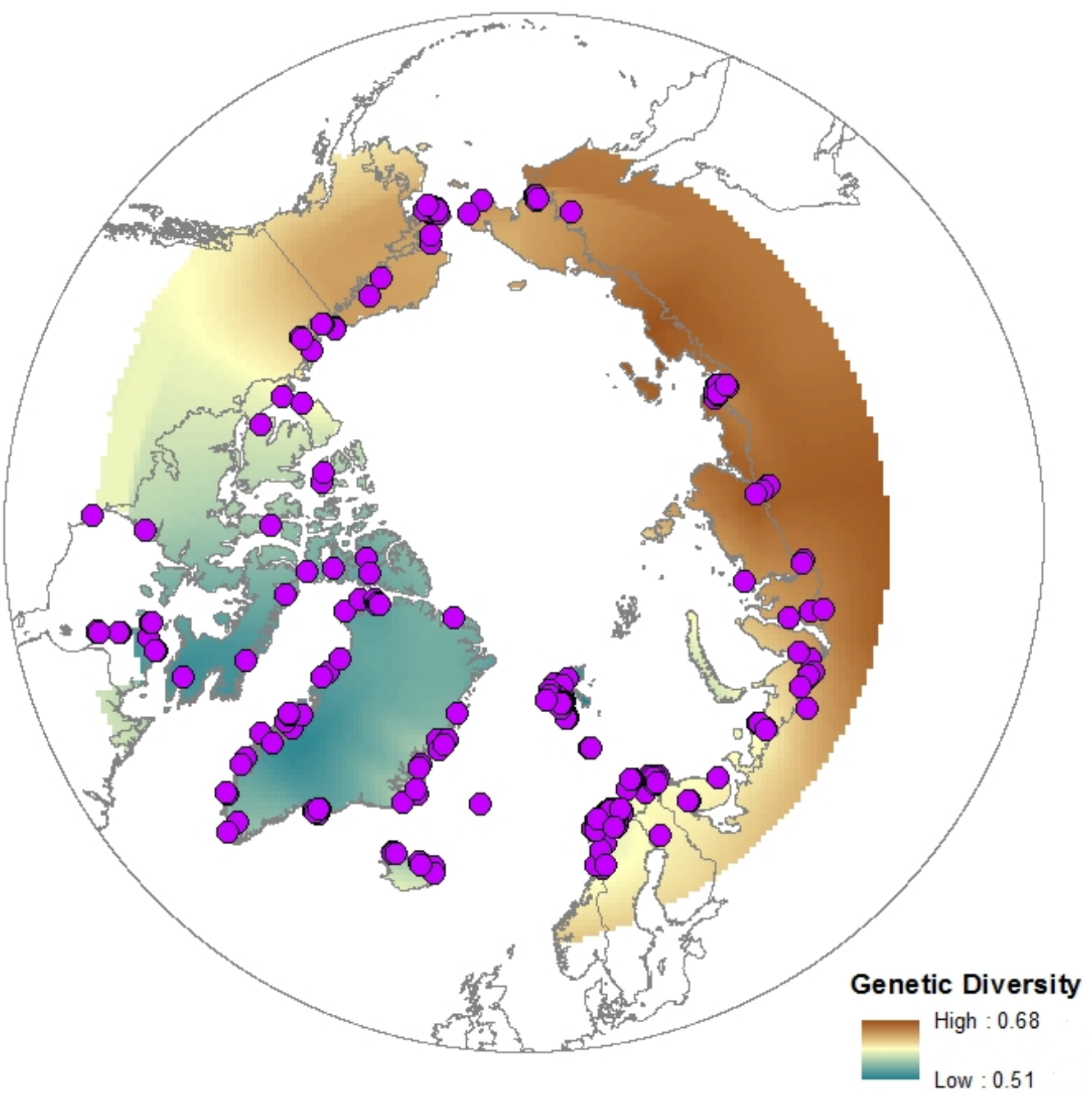

Figure 2. Map of interpolated genetic diversity across the Arctic. We assessed levels of genetic diversity inferred from Amplified Fragment Length Polymorphism (AFLP) variation in 23 relatively common arctic species from already published work (Appendix S3 in Supporting Information). Estimates of diversity (D) were transformed in order to enable the comparison between species following the formula: transformed value $=($ value $) /($ MAX value $)$. For each species the standardised genetic diversity was assigned to the grid cells where samples were available. The genetic diversity was then spatially interpolated to fill the unsampled grid cells within the outlined distribution range of each species and an average of all species was computed to produce the metamap for genetic diversity. Dots show where genetic data has been sampled. The projection used is North_Pole_Lambert_Azimuthal_Equal_Area_180. 
2015) and an average of all species was computed to produce a metamap for genetic diversity (Fig. 2).

\section{Predictor variables}

We compiled a set of macroclimatic predictor variables from WorldClim (Hijmans et al., 2005) (http://www.worldclim.org/) that are expected to contribute to explaining the variation in species richness across the Arctic. We chosemean temperature of the warmest quarter (hereafter temperature, Appendix S2), since it has previously been shown to be a strong predictor for plant diversity in the Arctic (Nilsen et al., 2013). Further we selected annual precipitation (hereafter precipitation, Appendix S2) as a measure of precipitation, since some areas in the Arctic are strongly influenced by summer rain (e.g. west Greenland, (Jensen, 2012)), while others that experience low levels of summer precipitation are more affected by the amount of snow during winter (e.g Zackenberg, (Hansen et al., 2008)). As a metric of landscape age since last deglaciation we used the map published by Raynolds \& Walker (2009) (Fig. 1). Landscape age was constructed based on information on the most recent deglaciation, emergence from sea, or drainage of proglacial lakes. The information was obtained from a compilation of Quaternary glaciations, available in digital format (Ehlers \& Gibbard, 2004). Areas of 21,000 years and older were regrouped into one age class. To test the importance of small scale habitat we analysed a homogenous subset of the data covering Russia and Svalbard for which local scale habitat information was recorded in the field (Appendix S3).

\section{Statistical analyses}

Because residuals from models on plot species richness are assumed to be spatially autocorrelated given the aggregated structure of vegetation plots along smooth climatic gradients (Fig. 1), we used 
a simultaneous autoregressive error model (SAR $\left.{ }_{\text {err }}\right)$ as suggested by Kissling and Carl (2008). We used a spatial weight matrix with neighbourhoods defined as all cells within $2000 \mathrm{~km}$ of the focal cell, and applied a Moran's I global test to determine whether residual autocorrelation persisted in the SAR models. To account for potential non-linear associations between richness and climatic variables, we tested the quadratic term of temperature and precipitation in the SAR models. The plot area variable was log-transformed prior to analyses, because this variable showed a power relationship with species richness, better fitted with a log transformation. Based on the full SAR models, information theoretic-based model selection was undertaken by comparing all competing models including all possible combinations of variables. To asses the fit of the model, we used the Akaike information criterion (AIC) (Burnham \& Anderson, 1998) as well as a metric of $\mathrm{R}^{2}$ as suggested by Kissling and Carl (2008) (hereafter called $\mathrm{R}^{2}$ ). We computed the $\mathrm{R}^{2}$ as the squared Pearson correlation between predicted and observed values to quantify the support for each model. To quantify the relative importance of variables in the model, we computed the Mean Squared Error (sum of squared differences between predicted and observed values divided by the number of observations) of the full model and the model with only a given environmental variable. Before running the SARerr models, all variables were scaled to zero mean and unit variance to be able to

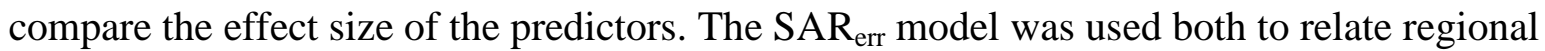
richness of vascular plants within the CAVM subregions of the Arctic (PAF data) as well as plot species richness of the three taxonomic groups and total species richness to all predictor variables. It was also used to relate regional species richness to genetic diversity of vascular plants and finally to relate genetic diversity to landscape age as well as current temperature. We further quantified the predictive power of all models beyond the calibration region, using geographically independent validation approach. For this, the study region was divided into a training and a testing region (Appendix S4). A SAR model fitted on the training half of the data was then projected in the testing 
half using the estimated parameters. Pearson correlations between predicted and observed values were used as a measure of predictive ability. Because the genetic diversity map was created using spatial interpolation, the model aiming to explain patterns in genetic diversity is expected to contain a particularly large amount of spatial autocorrelation. To test the importance of environmental variables relative to a pure spatial component, we calibrated the full SAR model, an intercept-only SAR model as well as an ordinary linear model (Appendix S5). Analyses were performed using R and the package “spdep” (Bivand, 2014).

\section{RESULTS}

\section{Species richness}

The regional diversity of vascular plants increased with increasing area, precipitation and landscape age (Table 1). Landscape age was the variable with the largest slope coefficient and the lowest partial MSE (Table 1), indicating that it had the strongest contribution in terms of explanatory power. Temperature was not significantly correlated with regional vascular plant species richness. Nevertheless, the standardised coefficients for temperature and precipitation were very similar, which suggests similar correlation between these two predictors and regional diversity. The explanatory power of the model for regional species richness was high compared to those for plot species richness. This is supported by our analysis showing that fine-scale habitat heterogeneity is an important driver of species richness at the plot scale (Appendix S3). The predictive ability in the geographically independent validation was high for species richness at this regional scale. The model calibrated in eastern North America-western Eurasia explained 75\% of the variation in richness in the other half of the Arctic (Appendix S6). 
Table 1. Summary of simultaneous autoregressive $\left(S A R_{\text {err }}\right)$ models of regional species richness of vascular plants (Elven et al., 2011) (nhm2.uio.no/paf) as a function of landscape age, size of the region (area), temperature and precipitation. The variable landscape age was published in Raynolds and Walker (2009). For temperature and precipitation we used the Bioclim variables mean temperature of the warmest quarter and annual precipitation from WorldClim (Hijmans et al., 2005) (http://www.worldclim.org/). All variables were scaled to zero mean and unit variance previous to analyses. $\mathrm{R}^{2}$ is calculated as the squared Pearson correlation between predicted and observed values (Kissling \& Carl, 2008). Mean Squared Error (MSE) is presented both for the full model and for models including one variable at a time (Partial MSE).

\begin{tabular}{|c|c|c|c|c|c|c|c|c|}
\hline Response & Predictor & Slope & p-value & SE & $\begin{array}{l}R^{2} \text { for the } \\
\text { full model }\end{array}$ & $\begin{array}{l}\text { MSE full } \\
\text { model }\end{array}$ & $\begin{array}{l}\text { Partial } \\
\text { MSE }\end{array}$ & $\begin{array}{l}\text { Sample size } \\
\text { (regions) }\end{array}$ \\
\hline \multirow{4}{*}{$\begin{array}{l}\text { Vascular } \\
\text { richness }\end{array}$} & Landscape age & 0.61 & $<<0.001$ & 0.16 & 0.76 & 0.23 & 0.69 & 23 \\
\hline & Precipitation & 0.47 & $<<0.001$ & 0.14 & & & 0.83 & \\
\hline & Temperature & 0.39 & 0.87 & 0.17 & & & 0.64 & \\
\hline & Area & 0.60 & $<<0.001$ & 0.12 & & & 0.85 & \\
\hline \multirow{2}{*}{$\begin{array}{l}\text { Vascular } \\
\text { richness }\end{array}$} & Genetic diversity & 0.46 & 0.02 & 0.19 & 0.30 & & 0.84 & \\
\hline & Area & 0.45 & 0.02 & 0.19 & & & 0.85 & \\
\hline
\end{tabular}


At the plot scale the number of bryophytes and lichens increased with the number of years since the ice retreated, while vascular plants showed no significant relationship and a low standardised coefficient (Table 2). All three groups of species showed significant correlations with both precipitation and temperature. The standardized coefficients were larger for precipitation than for temperature, but the partial MSE were lower for temperature, suggesting a contribution of both variables to explain plot richness. All groups except bryophytes (i.e. vascular plants, lichens, total species richness) were positively correlated with the size of the plots (Area, Table 2). At the plot scale models trained in eastern North America-western Eurasia explained 44\%, 64\%, -2\% and 25\% for total, vascular, bryophytes and lichens, in the other region respectively (Appendix S6), as has previously been found by others (Loreau, 2000; Lenoir et al., 2010).

\section{Genetic diversity}

The interpolated genetic diversity map (Fig. 2) indicated that genetic diversity in Eurasia increased from west to east, with lower levels in northern Fennoscandia and western Russia and higher levels in central and eastern Siberia (Beringia). In North America genetic diversity decreased from west to east. Genetic diversity was relatively high in Alaska (Beringia), while north eastern Canada and Greenland displayed the lowest values of genetic diversity. Interpolated genetic diversity generally corresponds to individual genetic diversity for the 23 species (Appendix S8). The SAR models showed a positive significant relationship between genetic diversity and landscape age as well as temperature (Table 2). The MSE was lower for landscape age than temperature, suggesting a stronger explanatory power of landscape age. The SAR model showed a high $\mathrm{R}^{2}$ (Table 2), which is probably a consequence of the spatial interpolation of the genetic diversity allowing the SAR spatial component to account for most of the variation. Nevertheless, a non-spatial model only based on environmental variable also showed a high $\mathrm{R}^{2}\left(\mathrm{R}^{2}=0.80\right.$, Appendix S5). In addition, the MSE of the 
Table 2. Summary of simultaneous autoregressive (SAR $\left.{ }_{\text {err }}\right)$ models of plot species richness (total, vascular, bryophytes and lichens) as a function of landscape age, plot size (area), temperature and precipitation as well as genetic diversity as function of landscape age and temperature. The variable landscape age was published in Raynolds and Walker (2009). For temperature and precipitation we used the Bioclim variables mean temperature of the warmest quarter and annual precipitation from WorldClim (Hijmans et al., 2005) (http://www.worldclim.org/). All variables were scaled to zero mean and unit variance previous to analyses. $\mathrm{R}^{2}$ is calculated as the squared Pearson correlation between predicted and observed values (Kissling \& Carl, 2008). Mean Standard Error (MSE) is presented both for the full model and for models including one variable at a time (Partial MSE).

\begin{tabular}{|c|c|c|c|c|c|c|c|c|}
\hline Response & Predictor & Slope & SE & p-value & $\begin{array}{l}R^{2} \text { for the } \\
\text { full model }\end{array}$ & $\begin{array}{l}\text { MSE full } \\
\text { model }\end{array}$ & $\begin{array}{l}\text { Partial } \\
\text { MSE }\end{array}$ & $\begin{array}{l}\text { Sample size } \\
\text { (number of } \\
\text { plots) }\end{array}$ \\
\hline \multirow{6}{*}{$\begin{array}{l}\text { Total } \\
\text { richness }\end{array}$} & Landscape age & 0.27 & 0.07 & $<<0.001$ & 0.46 & 3.44 & 1.12 & 4414 \\
\hline & Precipitation & 4.06 & 0.32 & $<<0.001$ & & & & \\
\hline & Precipitation^^2 & -3.55 & 0.25 & $<<0.001$ & & & 1.63 & \\
\hline & Temperature & 1.54 & 0.18 & $<<0.001$ & & & & \\
\hline & Temperature^^2 & -1.08 & 0.14 & $<<0.001$ & & & 1.00 & \\
\hline & Area & 0.16 & 0.02 & $<<0.001$ & & & 0.91 & \\
\hline \multirow{5}{*}{$\begin{array}{l}\text { Vascular } \\
\text { richness }\end{array}$} & Landscape age & 0.08 & 0.06 & 0.17 & 0.46 & 1.54 & 1.02 & 6192 \\
\hline & Precipitation & 1.39 & 0.25 & $<<0.001$ & & & & \\
\hline & Precipitation $\wedge 2$ & -1.43 & 0.21 & $<<0.001$ & & & 1.07 & \\
\hline & Temperature & 0.33 & 0.06 & $<<0.001$ & & & 1.18 & \\
\hline & Area & 0.13 & 0.02 & $<<0.001$ & & & 0.94 & \\
\hline \multirow{6}{*}{$\begin{array}{l}\text { Bryophyte } \\
\text { richness }\end{array}$} & Landscape age & 0.19 & 0.07 & 0.006 & 0.28 & 1.05 & 1.01 & 4427 \\
\hline & Precipitation & 2.17 & 0.25 & $<<0.001$ & & & & \\
\hline & Precipitation $\wedge 2$ & -2.23 & 0.23 & $<<0.001$ & & & 1.49 & \\
\hline & Temperature & 0.72 & 0.18 & $<<0.001$ & & & & \\
\hline & Temperature ${ }^{\wedge} 2$ & -0.83 & 0.15 & $<<0.001$ & & & 0.98 & \\
\hline & Area & 0.01 & 0.03 & 0.68 & & & 0.99 & \\
\hline \multirow{6}{*}{$\begin{array}{l}\text { Lichen } \\
\text { richness }\end{array}$} & Landscape age & 0.23 & 0.07 & 0.001 & 0.41 & 1.18 & 1.17 & 4431 \\
\hline & Precipitation & 2.39 & 0.26 & $<<0.001$ & & & & \\
\hline & Precipitation^^2 & -2.09 & 0.22 & $<<0.001$ & & & 1.57 & \\
\hline & Temperature & 0.69 & 0.17 & $<<0.001$ & & & & \\
\hline & Temperature $\wedge 2$ & -0.68 & 0.14 & $<<0.001$ & & & 0.93 & \\
\hline & Area & 0.16 & 0.02 & $<<0.001$ & & & 0.94 & \\
\hline \multirow{3}{*}{$\begin{array}{l}\text { Genetic } \\
\text { diversity }\end{array}$} & Landscape age & 0.02 & 0.003 & $<<0.001$ & 0.99 & 0.52 & 0.57 & 7509 \\
\hline & Temperature & 0.06 & 0.007 & $<<0.001$ & & & & \\
\hline & Temperature $\wedge 2$ & 0.09 & 0.005 & $<<0.001$ & & & 1.05 & \\
\hline
\end{tabular}


full model SARerr including all variables was almost half (MSE=0.52) that of the intercept-only model (MSE=1.22) accounting only for spatial co-variation, suggesting a clear model improvement when environmental variables are included. The model for genetic diversity calibrated in eastern North America-western Eurasia explained 83\% of the variation in richness in the testing region (eastern North America-western Eurasia) (Appendix S6). Genetic diversity of vascular plants was positively correlated with regional species richness of vascular plants (Table 1).

\section{DISCUSSION}

Here we evaluated whether landscape history in the Arctic is correlated with contemporary arctic vegetation diversity at two spatial scales, the plot and the regional species pool. Our results indicate that regional species richness and large scale patterns of genetic diversity are strongly associated with landscape age. This macroecological pattern is supported by high model transferability abilities across two main regions of the Arctic. In contrast, relationships at the plot scale are weaker with lower model transferability. Plot richness of bryophytes and lichens is correlated with landscape age, while richness of vascular plants is not related to landscape age. Our results therefore suggest a link between landscape age and vegetation diversity in the Arctic, but which depends on the spatial scale investigated.

Regional species diversity of vascular plants was associated with landscape age and both effect size and $\mathrm{R}^{2}$ for this model were relatively high, indicating that regional diversity of vascular plants may still be limited by postglacial migration lag. Our results provide evidence that in the arctic flora, as in other ecosystems (Ricklefs, 2004; Qian et al., 2007), glacial histories leave strong legacies in current species richness at large spatial scales. In contrast, landscape age explained little of the variation in species richness patterns at the plot scale (Appendix S3). Coarse scale climatic 
and historical variables used in the models are not sufficient to explain richness patterns at the plot scale because they are more influenced by local scale environment such as micro-topography (Crawley \& Harral, 2001; Willis \& Whittaker, 2002; Vellend et al., 2014). This conclusion is supported by the analysis of local scale micro-topography which had a larger effect size and smaller confidence intervals than landscape age in models from the subset of data covering Russia and Svalbard (Appendix S5). Note however that the remoteness and the large spatial extent of the study area constrained the use of existing plot data which are not equally distributed in the different landscape age categories (Fig. 1). A stratified vegetation sampling based on landscape age might have provided stronger relationships to landscape age.

As expected, the three taxonomic groups showed differential responses to time since deglaciation that may be linked to different dispersal abilities. A growing number of studies suggest that the spatial diversity of various groups of species within different ecosystems may be structured by dispersal-based processes (Qian, 2009; Beaudrot \& Marshall, 2011). Lenoir et al. (2012) found a high degree of similarity between lichen communities across the Eurasian arctic tundra, a result they attribute to the combination of effective wind-dispersal in northern circumpolar areas as well as the higher dispersal capacities of lichens compared to vascular plants or even bryophytes. Hence, lichens are likely to be in a degree of equilibrium with their current climatic conditions that is somewhat greater than vascular plants or bryophytes (Araujo \& Pearson, 2005). Lenoir et al. (2012) investigated macroscopically identifiable lichens whereas we only looked at terricolous species. Species with different life-forms may have very different dispersal strategies or experience various degrees of competition from vascular plants. Bültmann (2010) found a high degree of similarity for terricolous lichens along a south-north gradient from Italy to Greenland, a fact that she attributes to lichens being a common element of the periglacial tundra vegetation. We found landscape age to be positively correlated with lichen and bryophyte diversity but not with richness of vascular plants 
within plots. The higher species richness of lichens in older landscapes may result from an indirect edaphic effect. During succession over thousands of years, a maximal biomass stage is reached after which there is significant reduction in soil nutrients reducing productivity of vascular plants (Wardle et al., 2004). To what extent this is plausible for the Arctic is unknown but reduction in vascular plants have been found to favour occurrence of cryptogams (Pajunen et al., 2011). The fact that vascular plants, bryophytes and lichens have had different survival rates in climatically extreme microrefugia at higher latitudes and areas close to the ice sheets during the LGM (Rull, 2009) could also add to the taxon-specific patterns.

As expected based on the findings by Eidesen et al. (2013), Abbott et al. (2000) and Tollefsrud et al. (1998) the pattern of genetic diversity corresponds closely to the pattern of glaciation during the LGM. Ice-covered areas host significantly lower diversity than ice-free areas during glacial periods. The strong correlation of genetic diversity with time since ice retreat fits the model of loss of genetic diversity during successive bottlenecks during leading-edge expansion (Hewitt, 1996). Already in 1937, Hultén (1937) hypothesised the existence of a major refugium, Beringia, around the Bering Strait, and that the majority of arctic species spread from there following deglaciation. This idea has been supported by several later studies using phytogeographical, fossil (Abbott \& Brochmann, 2003) and molecular evidence (Abbott \& Brochmann, 2003; Eidesen et al., 2013). Our data corroborate Hultén’s hypothesis of initial radiation from Beringia, since this region displays a high degree of genetic diversity, which gradually declines in North America when moving east into the more recently glaciated areas. Moving west from Beringia into Eurasia, the genetic diversity remains high throughout Asia and then gradually declines westwards from the Urals, where glaciations have also been more severe (Astakhov, 2008). Moreover, the pattern we see that there are larger areas of high genetic diversity 
in Eurasia than in North America (Fig. 2) is consistent with the overall pattern of ice retreat after the LGM (Ehlers \& Gibbard, 2004).

We find a positive correlation between genetic diversity and regional species richness, thereby supporting the findings by Vellend et al. (2014) who found that correlations between species diversity and genetic diversity are generally positive, but the strength seems more pronounced at the coarser spatial scale within carefully selected regional vegetation units. The effect of landscape age seen in regional species richness recurs in genetic diversity which mainly reflects large-scale immigration patterns (Alsos et al., 2007). The bottleneck effect of postglacial recolonization might be very similar at interspecific and intraspecific levels.

Finally, the variables from Worldclim (Hijmans et al., 2005) describing current climate conditions were significant for all species groups. Temperature (Odland \& Birks, 1999; Nilsen et al., 2013) and precipitation (Odland \& Birks, 1999) have previously been found to drive diversity patterns at various spatial scales. However, at all scales considered we found that temperature was not the main correlate of vegetation diversity, which is in contrast to other studies (Currie, 1991; Currie et al., 2004), and precipitation showed a stronger effect in several models. Both temperature and precipitation are expected to control species richness but possibly with different intensity in different areas (Grytnes, 2003). In addition, since we focus on an ecosystem beyond the tree line, the temperature will globally show lower variation and have a lower importance in models.

Our study shows that we can still detect imprints of past glaciations on diversity patterns of arctic vegetation, at least for regional diversity. Current patterns of regional species richness of vascular plants as well as genetic diversity are still strongly affected by historical processes associated with the time and habitat available for dispersal and colonisation. This leaves important implications for the response of arctic vegetation to ongoing climate change as well as for models trying to forecast future distributions. If we mistakenly assume that species are at present in 
equilibrium, predictions of species responses to future changes will most certainly be inaccurate. Vascular plants have not been able to track climatic changes during the Quaternary, at least not at the regional scale, and are therefore expected to have even more difficulty tracking ongoing climate change. The positive relationship seen for regional vascular plant species richness does not recur in plot species richness indicating that richness at this scale is more determined by local and landscape scale parameters (Lenoir et al., 2010). The impact of ongoing climate change on species diversity may thus vary largely across scales and monitoring of change both at regional and plot scale is essential to understand ongoing processes. Our study illustrates the strength of investigating vegetation diversity across different scales to understand the consequences of climate change on vegetation patterns.

\section{ACKNOWLEDGEMENTS}

Compilation of the species richness data was made possible through the TFI Networks grant to CD, "Effect Studies and Adaptation to Climate Change," under the Norforsk initiative (2011 - 2014) which supported two CBIONET-AVA workshops held in Denmark during 2013. The genetic studies were funded by the Research Council of Norway (grant nos. 150322/720 and 170952/V40 to CB). We extend our sincere thanks to Mads C. Forchhammer for highly valuable comments and discussions on earlier versions of the manuscript 


\section{REFERENCES}

Abbott, R.J. \& Brochmann, C. (2003) History and evolution of the arctic flora: in the footsteps of Eric Hulten. Molecular Ecology, 12, 299-313.

Abbott, R.J., Smith, L.C., Milne, R.I., Crawford, R.M.M., Wolff, K. \& Balfour, J. (2000) Molecular analysis of plant migration and refugia in the Arctic. Science, 289, 1343-1346.

Ackerly, D. (2009) Conservatism and diversification of plant functional traits: Evolutionary rates versus phylogenetic signal. Proceedings of the National Academy of Sciences of the United States of America, 106, 19699-19706.

Adams, R.I. \& Vellend, M. (2011) Species diversity of grasses promotes genotypic diversity of clover populations in simulated communities. Oikos, 120, 1584-1594.

Alsos, I.G., Eidesen, P.B., Ehrich, D., Skrede, I., Westergaard, K., Jacobsen, G.H., Landvik, J.Y., Taberlet, P. \& Brochmann, C. (2007) Frequent long-distance plant colonization in the changing Arctic. Science, 316, 1606-1609.

Alsos, I.G., Ehrich, D., Thuiller, W., Eidesen, P.B., Tribsch, A., Schonswetter, P., Lagaye, C., Taberlet, P. \& Brochmann, C. (2012) Genetic consequences of climate change for northern plants. Proceedings of the Royal Society B-Biological Sciences, 279, 2042-2051.

Araujo, M.B. \& Pearson, R.G. (2005) Equilibrium of species' distributions with climate. Ecography, 28, 693695.

Astakhov, V. (2008) Geographical extremes in the glacial history of northern Eurasia: post-QUEEN considerations. Polar Research, 27, 280-288.

Beaudrot, L.H. \& Marshall, A.J. (2011) Primate communities are structured more by dispersal limitation than by niches. Journal of Animal Ecology, 80, 332-341.

Bennike, O., Bjorck, S., Bocher, J., Hansen, L., Heinemeier, J. \& Wohlfarth, B. (1999) Early holocene plant and animal remains from North-east Greenland. Journal of Biogeography, 26, 667-677.

Birks, H.H., Paus, A., Svendsen, J.I., Alm, T., Mangerud, J. \& Landvik, J.Y. (1994) Late Weichselian environmental-change in Norway, including Svalbard. Journal of Quaternary Science, 9, 133-145.

Bivand, R. (2014) spdep: Spatial dependence: weighting schemes, staistics and models. R package version 0.5-71.

Brochmann, C., Edwards, M.E. \& Alsos, I.G. (2013) The dynamic past and future of arctic plants: climate change, spatial variation, and genetic diversity. The Balance of Nature and Human Impact (ed. by K. Rohde), pp. 133-152. Cambridge University Press, Cambridge, UK.

Brochmann, C., Gabrielsen, T.M., Nordal, I., Landvik, J.Y. \& Elven, R. (2003) Glacial survival or tabula rasa? The history of North Atlantic biota revisited. Taxon, 52, 417-450.

Brubaker, L.B., Anderson, P.M. \& Hu, F.S. (1995) Arctic tundra biodiversity: A temporal perspective from Late Quaternary pollen records. Arctic and Alpine Biodiversty: Patterns, Causes and Ecosystem Consequences (ed. by F.S.I. Chapin and C. Körner), pp. 111-125.

Burnham, K.P. \& Anderson, D.R. (1998) Model selection and multimodel inference: a practical informationtheoretic approach. Springer, New York, USA.

CAFF (2013) Arctic Biodiversity Assessment. Status and trends in Arctic Biodiversity. Conservation of Arctic Flora and Fauna, Akureyri.

Callaghan, T.V., Bjørn, L.O., Chapin III, F.S., Chernov, Y., Christensen, T.R., Huntley, B., Ims, R.A., Johansson, M., Riedlinger, D.J., Jonasson, S., Matveyeva, N., Oechel, W., Panikov, N. \& Shaver, G. (2005) Arctic tundra and polar desert ecosystems. Artic Climate Impact Assessmen (ACIA), pp. 243-352. Cambridge University Press, Cambridge, UK.

CAVM Team (2003) Circumpolar Arctic Vegetation Map. (1:7,500,000 scale) Conservation of Arctic Flora and Fauna (Caff) Map No. 1. Fish and Wildlife Service Anchorage, Alaska

Crawford, R.M.M., Jeffree, C.E. \& Rees, W.G. (2003) Paludification and forest retreat in northern oceanic environments. Annals of Botany, 91, 213-226.

Crawley, M.J. \& Harral, J.E. (2001) Scale dependence in plant biodiversity. Science, 291, 864-868. 
Currie, D.J. (1991) ENERGY AND LARGE-SCALE PATTERNS OF ANIMAL-SPECIES AND PLANT-SPECIES RICHNESS. American Naturalist, 137, 27-49.

Currie, D.J., Mittelbach, G.G., Cornell, H.V., Field, R., Guegan, J.F., Hawkins, B.A., Kaufman, D.M., Kerr, J.T., Oberdorff, T., O'Brien, E. \& Turner, J.R.G. (2004) Predictions and tests of climate-based hypotheses of broad-scale variation in taxonomic richness. Ecology Letters, 7, 1121-1134.

de Vernal, A. \& Hillaire-Marcel, C. (2008) Natural variability of Greenland climate, vegetation, and ice volume during the past million years. Science, 320, 1622-1625.

Ehlers, J. \& Gibbard, P.L. (2004) Quaternary glaciations - extent and chronology. Elsevier B.V., Amsterdam, The Netherlands.

Eidesen, P.B., Ehrich, D., Bakkestuen, V., Alsos, I.G., Gilg, O., Taberlet, P. \& Brochmann, C. (2013) Genetic roadmap of the Arctic: plant dispersal highways, traffic barriers and capitals of diversity. New Phytologist, 200, 898-910.

Elven, R., Murray, D.F., Razzhivin, V.Y. \& Yurtsev, B.A. 2011 Annotated checklist of the panarctic flora (PAF) http://nhm2.uio.no/paf/ National History Museum, University of Oslo

Excoffier, L., Foll, M. \& Petit, R.J. (2009) Genetic consequences of range expansions. Annual Review of Ecology Evolution and Systematics, pp. 481-501. Annual Reviews, Palo Alto.

Funder, S., Bennike, O., Bocher, J., Israelson, C., Petersen, K.S. \& Simonarson, L.A. (2001) Late Pliocene Greenland - The Kap Kobenhavn Formation in North Greenland. Bulletin of the Geological Society of Denmark, 48, 117-134.

Grytnes, J.A. (2003) Species-richness patterns of vascular plants along seven altitudinal transects in Norway. Ecography, 26, 291-300.

Hansen, B.U., Sigsgaard, C., Rasmussen, L., Cappelen, J., Hinkler, J., Mernild, S.H., Petersen, D., Tamstorf, M.P., Rasch, M. \& Hasholt, B. (2008) Present-day climate at Zackenberg. Advances in Ecological Research, Vol 40: High-Arctic Ecosystem Dynamics in a Changing Climate (ed. by H. Meltofte, T.R. Christensen, B. Elberling, M.C. Forchhammer and M. Rasch), pp. 111-149. Elsevier Academic Press Inc, San Diego.

He, T.H., Lamont, B.B., Krauss, S.L., Enright, N.J. \& Miller, B.P. (2008) Covariation between intraspecific genetic diversity and species diversity within a plant functional group. Journal of Ecology, 96, 956961.

Hewitt, G.M. (1996) Some genetic consequences of ice ages, and their role in divergence and speciation. Biological Journal of the Linnean Society, 58, 247-276.

Hijmans, R.J., Cameron, S.E., Parra, J.L., Jones, P.G. \& Jarvis, A. (2005) Very high resolution interpolated climate surfaces for global land areas. International Journal of Climatology, 25, 1965-1978.

Hoffmann, M.H., von Hagen, K.B., Horandl, E., Roser, M. \& Tkach, N.V. (2010) Sources of the arctic flora: Origins of arctic species in Ranunculus and related genera. International Journal of Plant Sciences, 171, 90-106.

Hultén, E. (1937) Outline of the history of arctic and boreal biota during the Quaternary period: their evolution during and after the glacial period as indicated by the equiformal progressive areas of present plant species, Stockholm, Sweden: Thule.

Jensen, L.M. (ed.) (2012) Nuuk Ecological Research Operations, 5th Annual Report, 2011, Aarhus University, DCE - Danish Centre for Environment and Energy.

Jump, A.S., Marchant, R. \& Penuelas, J. (2009) Environmental change and the option value of genetic diversity. Trends in Plant Science, 14, 51-58.

Kappen, L. (1993) Plant activity under snow and ice, with particular reference to lichens. Arctic, 46, 297302.

Keitt, T.H., Bivand, R., Pebesma, E. \& Rowlingson, B. (2013) rgdal: bindings for the geospatial data abstraction library. R package.

Kienast, F., Wetterich, S., Kuzmina, S., Schirrmeister, L., Andreev, A.A., Tarasov, P., Nazarova, L., Kossler, A., Frolova, L. \& Kunitsky, V.V. (2011) Paleontological records indicate the occurrence of open 
woodlands in a dry inland climate at the present-day Arctic coast in western Beringia during the Last Interglacial. Quaternary Science Reviews, 30, 2134-2159.

Kissling, W.D. \& Carl, G. (2008) Spatial autocorrelation and the selection of simultaneous autoregressive models. Global Ecology and Biogeography, 17, 59-71.

Lenoir, J. \& Svenning, J.C. (2013) Latitudinal and elevational range shifts under contemporary climate change. Encyclopedia of Biodiversity (ed. by S.A. Levin), pp. 599-611. Elsevier Science Publishing Co Inc.

Lenoir, J., Virtanen, R., Oksanen, J., Oksanen, L., Luoto, M., Grytnes, J.A. \& Svenning, J.C. (2012) Dispersal ability links to cross-scale species diversity patterns across the Eurasian Arctic tundra. Global Ecology and Biogeography, 21, 851-860.

Lenoir, J., Gegout, J.C., Guisan, A., Vittoz, P., Wohlgemuth, T., Zimmermann, N.E., Dullinger, S., Pauli, H., Willner, W., Grytnes, J.A., Virtanen, R. \& Svenning, J.C. (2010) Cross-scale analysis of the region effect on vascular plant species diversity in southern and northern European mountain ranges. Plos One, 5

Loreau, M. (2000) Are communities saturated? On the relationship between alpha, beta and gamma diversity. Ecology Letters, 3, 73-76.

Moeslund, J.E., Arge, L., Bocher, P.K., Dalgaard, T. \& Svenning, J.C. (2013) Topography as a driver of local terrestrial vascular plant diversity patterns. Nordic Journal of Botany, 31, 129-144.

Munoz, J., Felicisimo, A.M., Cabezas, F., Burgaz, A.R. \& Martinez, I. (2004) Wind as a long-distance dispersal vehicle in the Southern Hemisphere. Science, 304, 1144-1147.

Nilsen, L., Arnesen, G., Joly, D. \& Malnes, E. (2013) Spatial modelling of Arctic plant diversity. Biodiversity, 14, 67-78.

Normand, S., Randin, C., Ohlemuller, R., Bay, C., Hoye, T.T., Kjaer, E.D., Korner, C., Lischke, H., Maiorano, L., Paulsen, J., Pearman, P.B., Psomas, A., Treier, U.A., Zimmermann, N.E. \& Svenning, J.C. (2013) A greener Greenland? Climatic potential and long-term constraints on future expansions of trees and shrubs. Philosophical Transactions of the Royal Society B-Biological Sciences, 368

Odland, A. \& Birks, H.J.B. (1999) The altitudinal gradient of vascular plant richness in Aurland, western Norway. Ecography, 22, 548-566.

Pajunen, A.M., Oksanen, J. \& Virtanen, R. (2011) Impact of shrub canopies on understorey vegetation in western Eurasian tundra. Journal of Vegetation Science, 22, 837-846.

Puscas, M., Taberlet, P. \& Choler, P. (2008) No positive correlation between species and genetic diversity in European alpine grasslands dominated by Carex curvula. Diversity and Distributions, 14, 852-861.

Qian, H. (2009) Beta diversity in relation to dispersal ability for vascular plants in North America. Global Ecology and Biogeography, 18, 327-332.

Qian, H., White, P.S. \& Song, J.S. (2007) Effects of regional vs. ecological factors on plant species richness: An intercontinental analysis. Ecology, 88, 1440-1453.

Raynolds, M.K. \& Walker, D.A. (2009) Effects of deglaciation on circumpolar distribution of arctic vegetation. Canadian Journal of Remote Sensing, 35, 118-129.

Ricklefs, R.E. (2004) A comprehensive framework for global patterns in biodiversity. Ecology Letters, 7, 1-15.

Rull, V. (2009) Microrefugia. Journal of Biogeography, 36, 481-484.

Sandel, B., Arge, L., Dalsgaard, B., Davies, R.G., Gaston, K.J., Sutherland, W.J. \& Svenning, J.C. (2011) The influence of Late Quaternary climate-change velocity on species endemism. Science, 334, 660-664.

Svendsen, J.I., Alexanderson, H., Astakhov, V.I., Demidov, I., Dowdeswell, J.A., Funder, S., Gataullin, V., Henriksen, M., Hjort, C., Houmark-Nielsen, M., Hubberten, H.W., Ingolfsson, O., Jakobsson, M., Kjaer, K.H., Larsen, E., Lokrantz, H., Lunkka, J.P., Lysa, A., Mangerud, J., Matiouchkov, A., Murray, A., Moller, P., Niessen, F., Nikolskaya, O., Polyak, L., Saarnisto, M., Siegert, C., Siegert, M.J., Spielhagen, R.F. \& Stein, R. (2004) Late Quaternary ice sheet history of northern Eurasia. Quaternary Science Reviews, 23, 1229-1271.

Svenning, J.C. \& Sandel, B. (2013) Disequilibrium vegetation dynamics under future climate change. American Journal of Botany, 100, 1266-1286. 
Taberlet, P., Zimmermann, N.E., Englisch, T., Tribsch, A., Holderegger, R., Alvarez, N., Niklfeld, H., Coldea, G., Mirek, Z., Moilanen, A., Ahlmer, W., Marsan, P.A., Bona, E., Bovio, M., Choler, P., Cieslak, E., Colli, L., Cristea, V., Dalmas, J.P., Frajman, B., Garraud, L., Gaudeul, M., Gielly, L., Gutermann, W., Jogan, N., Kagalo, A.A., Korbecka, G., Kupfer, P., Lequette, B., Letz, D.R., Manel, S., Mansion, G., Marhold, K., Martini, F., Negrini, R., Nino, F., Paun, O., Pellecchia, M., Perico, G., Piekos-Mirkowa, H., Prosser, F., Puscas, M., Ronikier, M., Scheuerer, M., Schneeweiss, G.M., Schonswetter, P., Schratt-Ehrendorfer, L., Schupfer, F., Selvaggi, A., Steinmann, K., Thiel-Egenter, C., van Loo, M., Winkler, M., Wohlgemuth, T., Wraber, T., Gugerli, F. \& IntraBioDiv, C. (2012) Genetic diversity in widespread species is not congruent with species richness in alpine plant communities. Ecology Letters, 15, 1439-1448.

Team, R.C. (2015) R: A language and environment for statistical computing. R Foundation for Statistical Computing.

Thuiller, W., Lavorel, S., Araujo, M.B., Sykes, M.T. \& Prentice, I.C. (2005) Climate change threats to plant diversity in Europe. Proceedings of the National Academy of Sciences of the United States of America, 102, 8245-8250.

Tilman, D., May, R.M., Lehman, C.L. \& Nowak, M.A. (1994) Habitat destruction and extinction debt. Nature, 371, 65-66.

Tollefsrud, M.M., Bachmann, K., Jakobsen, K.S. \& Brochmann, C. (1998) Glacial survival does not matter - II: RAPD phylogeography of Nordic Saxifraga cespitosa. Molecular Ecology, 7, 1217-1232.

Vellend, M. (2005) Species diversity and genetic diversity: Parallel processes and correlated patterns. American Naturalist, 166, 199-215.

Vellend, M. \& Geber, M.A. (2005) Connections between species diversity and genetic diversity. Ecology Letters, 8, 767-781.

Vellend, M., Lajoie, G., Bourret, A., Murria, C., Kembel, S.W. \& Garant, D. (2014) Drawing ecological inferences from coincident patterns of population- and community-level biodiversity. Molecular Ecology, 23, 2890-2901.

Walker, D.A., Raynolds, M.K., Daniëls, F.J.A., Einarsson, E., Elvebakk, A., Gould, W.A., Katenin, A.E., Kholod, S.S., Markon, C.J., Melnikov, E.S., Moskalenko, N.G., Talbot, S.S., Yurtsev, B.A. \& CAVM Team (2005) The Circumpolar Arctic Vegetation Map. Journal of Vegetation Science, 16, 267-282.

Wardle, D.A., Walker, L.R. \& Bardgett, R.D. (2004) Ecosystem properties and forest decline in contrasting long-term chronosequences. Science, 305, 509-513.

Willis, K.J. \& Whittaker, R.J. (2002) Ecology - species diversity - scale matters. Science, 295, 1245-+.

Yannic, G., Pellissier, L., Ortego, J., Lecomte, N., Couturier, S., Cuyler, C., Dussault, C., Hundertmark, K.J., Irvine, R.J., Jenkins, D.A., Kolpashikov, L., Mager, K., Musiani, M., Parker, K.L., Roed, K.H., Sipko, T., Porisson, S.G., Weckworth, B.V., Guisan, A., Bernatchez, L. \& Cote, S.D. (2014) Genetic diversity in caribou linked to past and future climate change. Nature Climate Change, 4, 132-137.

\section{BIOSKETCH}

Lærke Stewart is a Ph.d. student at the Department of Bioscience, Århus University. Her research focuses on distribution of arctic vegetation and how these patterns change with a changing climate. She works at small as well as large spatial extents, using empirical data and spatial modelling to answer questions about species, community and diversity distributions.

The current project was a collaborative research effort to put together small scale data for an entire biome to analyse patterns of species diversity. 
Author contributions: The study was designed by LS, JCS, MSW, NMS and LP. Data was collected by LS, IGA, CB, ALB, CB, NBL, HB, FJAD, DE, PBE, ISJ, EL, ML, JNN, PS, AT, LUT, RV, DAW and KBW. LS and LP conducted the analyses with the help of NMS, JCS, MSW, PKB and CD. LS lead the writing with contribution from all co-authors. 


\section{Appendix S1 Circumpolar Arctic Vegetation Map}

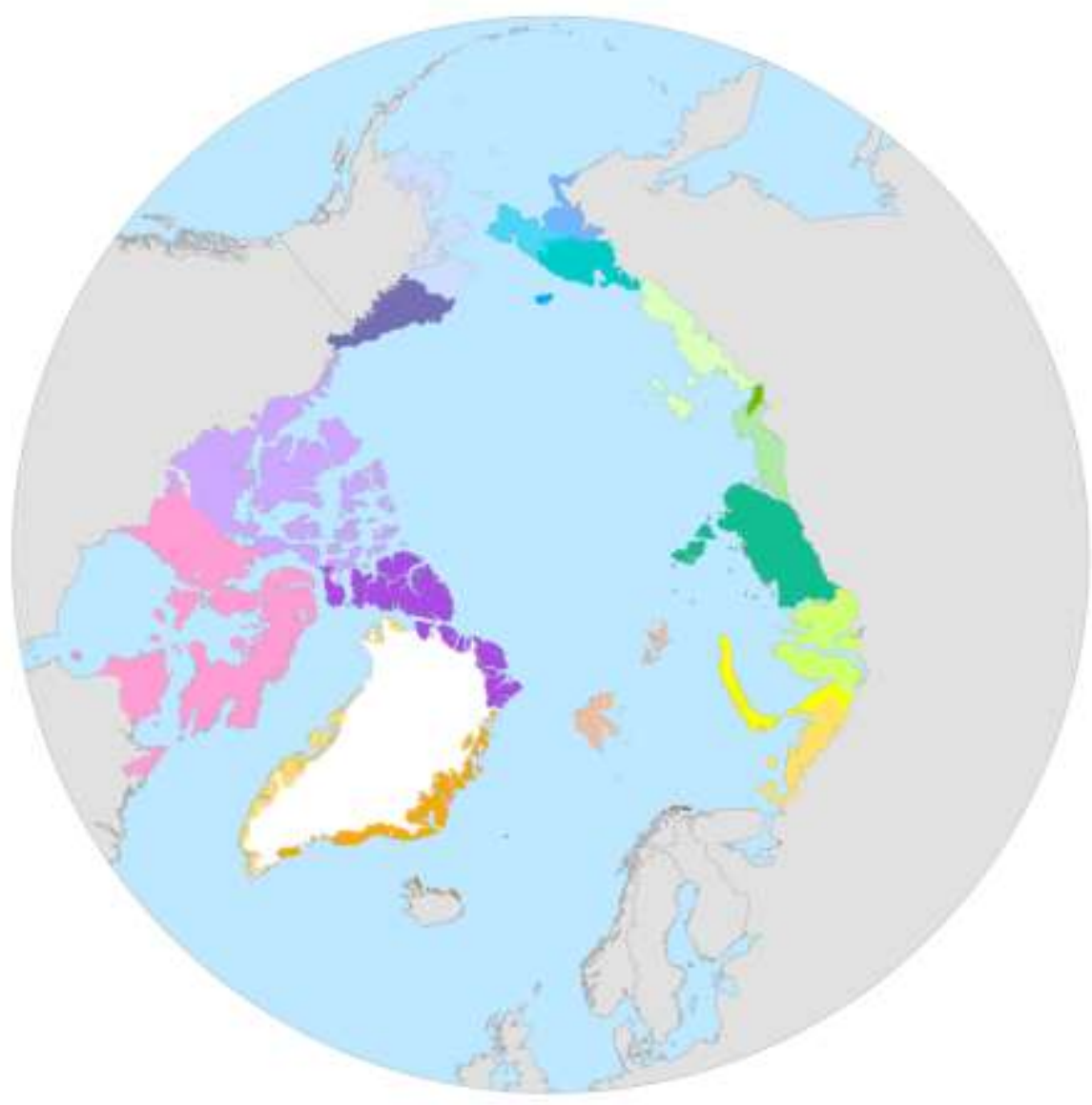

Circumpolar Arctic Vegetation Map Floristic Provinces

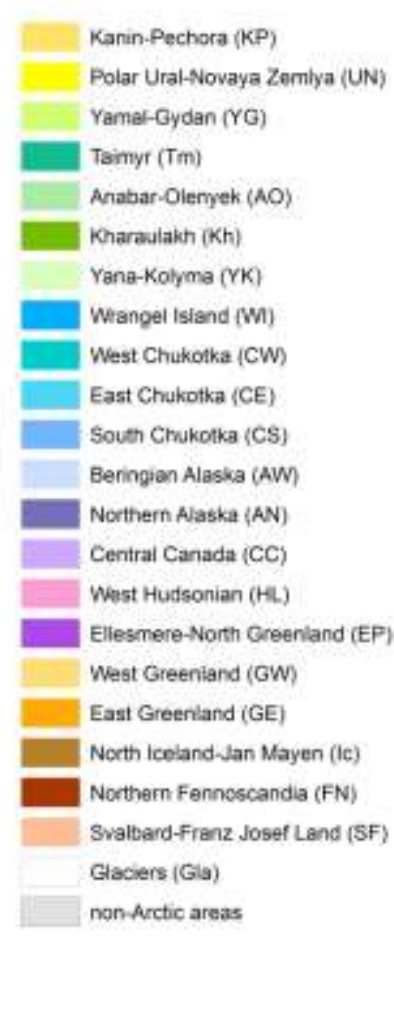

Figure S1: Map of the Arctic and surrounding areas. The Arctic was divided into 21 subsections based on floristic variation. Modified from CAVM Team (2003).

CAVM Team (2003) Circumpolar Arctic Vegetation Map. (1:7,500,000 scale) Conservation of Arctic Flora and Fauna (Caff) Map No. 1. Fish and Wildlife Service Anchorage, Alaska 


\section{Appendix S2 Table showing all datasets of plot species richness}

Table S2: Data sets used in analyses of species richness. For references see appendix 1.

\begin{tabular}{|c|c|c|c|}
\hline Location & Data set & Number of plots & Reference \\
\hline Alaska (USA) & HappyValley & 43 & (Walker et al., 1997) \\
\hline Alaska (USA) & Imnavait & 61 & (Walker et al., 1987; Walker et al., 1994) \\
\hline Alaska (USA) & Pingo & 293 & (Walker, 1990) \\
\hline Alaska (USA) & Toolik & 79 & $\begin{array}{l}\text { (Walker \& Barry, 1991; Walker et al., } \\
\text { 1994) }\end{array}$ \\
\hline $\begin{array}{l}\text { Alaska and Canada } \\
\text { (USA/CDN) }\end{array}$ & NAAT & 187 & $\begin{array}{l}\text { (Munger } \text { et al., 2003; Kade } \text { et al., 2005; } \\
\text { Munger } \text { et al., 2005; Barreda } \text { et al., 2006; } \\
\text { Vonlanthen } \text { et al., 2006; Vonlanthen } \text { et } \\
\text { al., 2008; Walker } \text { et al., 2011) }\end{array}$ \\
\hline Ammassalik (GL) & Ammassalik_Daniëls & 132 & $\begin{array}{l}\text { (Daniëls \& de Molenaar, 2011; Daniëls et } \\
\text { al., 2011) }\end{array}$ \\
\hline Bylot (CDN) & EstherBylot & 255 & (Duclos et al., 2006) \\
\hline Iceland (IS) & ITEX Audkuluheidi & 10 & (Jonsdottir et al., 2005) \\
\hline Iceland (IS) & ITEX Thingvellir & 10 & (Jonsdottir et al., 2005) \\
\hline Jan Mayen $(\mathrm{N})$ & Risto Jan Mayen & 210 & (Kapfer et al., 2012) \\
\hline Kangerlussuaq (GL) & Hüls & 122 & (Hüls, 2002) \\
\hline Kobbefjord (GL) & Bryophyte Kob & 6 & (Hassel et al., 2012) \\
\hline N Feno (N/FIN) & Miska_Jonathan & 1308 & (le Roux et al., 2013) \\
\hline Ngreenland (GL) & FJAD, N Greenland & 75 & (Daniëls Unpublished) \\
\hline N.Greenland (GL) & PrIngeborgPeninsula & 14 & (Bay, 1997) \\
\hline Nuuk fjord (GL) & Nabe & 306 & $\begin{array}{l}\text { (Nabe-Nielsen \& Forchhammer } \\
\text { unpublished) }\end{array}$ \\
\hline Russia (RUS) & Risto & 992 & (Virtanen et al., 2006) \\
\hline Svalbard (N) & Risto & 140 & (Virtanen et al., 2006) \\
\hline Sverdrup (CDN) & EstherEllesmere & 1099 & (Lévesque, 1997) \\
\hline Sverdrup (CDN) & FJAD, Canada & 42 & (Daniëls Unpublished) \\
\hline West Greenland (GL) & FJAD, W Greenland & 15 & (Daniëls Unpublished) \\
\hline West Greenland (GL) & Sieg02 & 250 & $\begin{array}{l}\text { (Sieg \& Daniëls, 2005; Sieg et al., 2006; } \\
\text { Sieg et al., 2009) }\end{array}$ \\
\hline West Greenland (GL) & Sieg06 & 46 & $\begin{array}{l}\text { (Sieg \& Daniëls, 2005; Sieg et al., 2006; } \\
\text { Sieg et al., 2009) }\end{array}$ \\
\hline West Greenland (GL) & Sult & 145 & (Sult, 2002) \\
\hline West Greenland (GL) & SultDrees & 254 & (Drees \& Daniëls, 2009) \\
\hline Zackenberg (GL) & Bryophyte Zack & 7 & (Hassel et al., 2012) \\
\hline Zackenberg (GL) & Lichen Zack & 17 & (Jensen, 2012) \\
\hline Zackenberg (GL) & ZERO line & 104 & (Klitgaard et al., 2006) \\
\hline
\end{tabular}




\section{Appendix S3 Table showing all datasets used in analyses of genetic diversity}

Table S3: Species used in analyses of genetic diversity. For references see appendix 2.

\begin{tabular}{|l|l|}
\hline Species & References \\
\hline Angelica archangelica & (Alsos et al., 2012; Eidesen et al., 2013) \\
\hline Arenaria humifusa & (Westergaard et al., 2011) \\
\hline Arctous alpinus & (Alsos et al., 2012; Eidesen et al., 2013) \\
\hline Avenella flexuosa & (Alsos et al., 2012; Eidesen et al., 2013) \\
\hline Betula nana & (Alsos et al., 2012; Eidesen et al., 2013) \\
\hline Betula pubescens & (Alsos et al., 2012; Eidesen et al., 2013) \\
\hline Carex atrofusca & (Schonswetter et al., 2006a) \\
\hline Carex bigelowii & (Schonswetter et al., 2008) \\
\hline Cassiope tetragona & (Alsos et al., 2012; Eidesen et al., 2013) \\
\hline Chamerion angustifolium & (Alsos et al., 2012; Eidesen et al., 2013) \\
\hline Dryas octopetala & (Skrede et al., 2006; Alsos et al., 2012; \\
& Eidesen et al., 2013) \\
\hline Empetrum nigrum s.lat. & (Alsos et al., 2012; Eidesen et al., 2013) \\
\hline Juncus biglumis & (Schonswetter et al., 2007) \\
\hline Juniperus communis & (Alsos et al., 2012; Eidesen et al., 2013) \\
\hline Loiseleuria procumbens & (Alsos et al., 2012; Eidesen et al., 2013) \\
\hline Minuartia biflora & (Schonswetter et al., 2006b) \\
\hline Ranunculus pygmaeus & (Schonswetter et al., 2006b) \\
\hline Rubus chamaemorus & (Ehrich et al., 2008) \\
\hline Sagina caespitosa & (Westergaard et al., 2011) \\
\hline Salix herbaceae & (Alsos et al., 2009) \\
\hline Saxifraga rivularis & (Westergaard et al., 2010) \\
\hline Vaccinium uliginosum & (Alsos et al., 2012; Eidesen et al., 2013) \\
\hline Vaccinium vitis-idaea & (Eidesen, 2007) \\
\hline
\end{tabular}



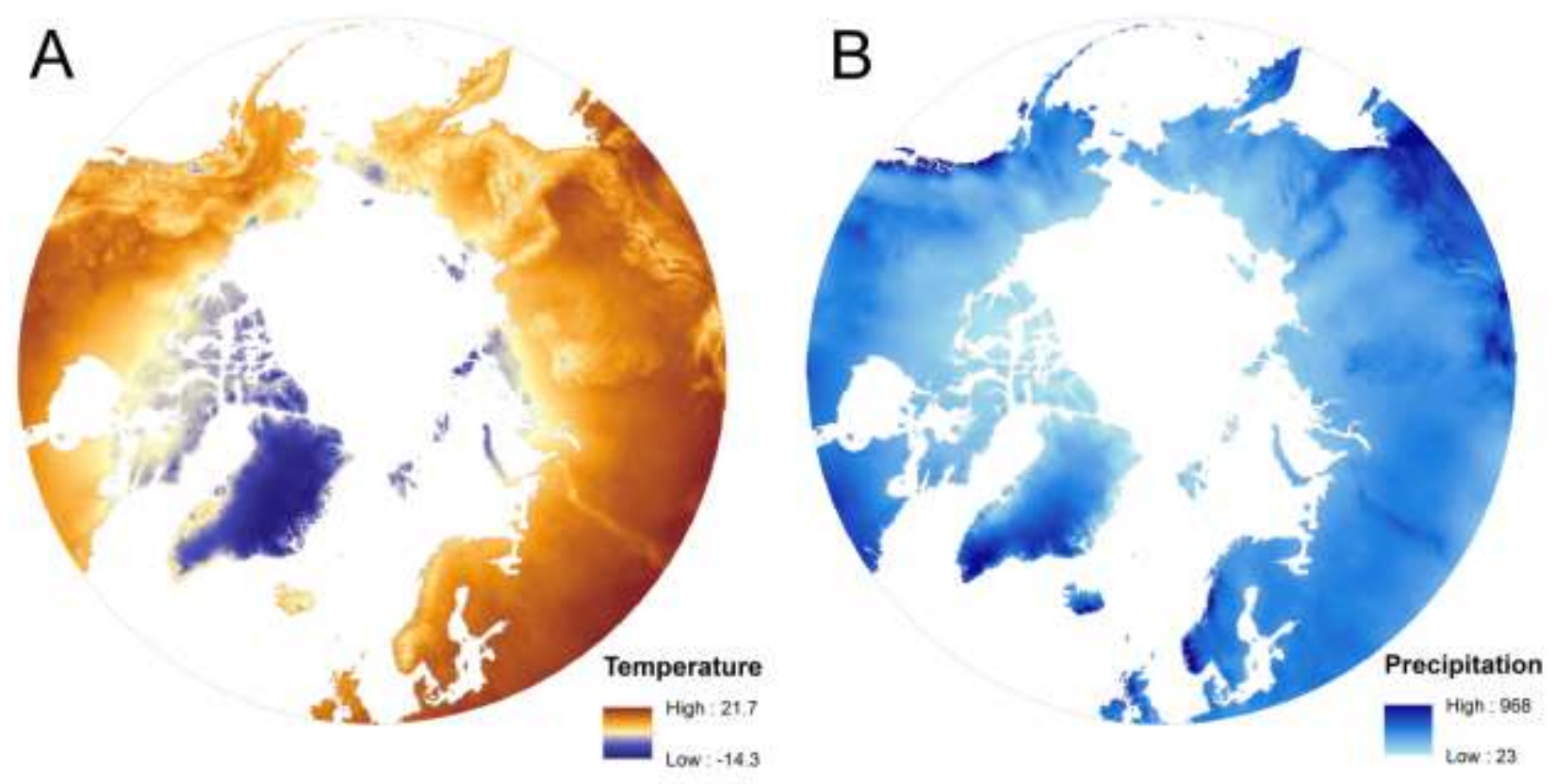

Figure S4: Maps of the Arctic and surrounding areas. A: Map of mean temperetarure of the warmest quarter expressed as degree Celsius, B: Map of annual precipitation in $\mathrm{mm}$. 


\section{Appendix S5 Results of generalised linear models}

Table S5. Summary of generalised linear models (glm) of plot species richness (total, vascular, bryophytes and lichens) as a function of landscape age, plot size (area), temperature and precipitation as well as genetic diversity as function of landscape age and temperature. The variable landscape age was published in Raynolds and Walker (2009). For temperature and precipitation we used the Bioclim variables mean temperature of the warmest quarter and annual precipitation from WorldClim (Hijmans et al., 2005) (http://www.worldclim.org/). Glm's were fitted using gaussian distribution. Data was scaled to cero mean and unit variance. $\mathrm{R}^{2}$ is calculated as the squared Pearson correlation between predicted and observed values (Kissling \& Carl, 2008). Mean Squared Error (MSE) is presented both for the full model and for models including one variable at a time (Partial MSE)

\begin{tabular}{|c|c|c|c|c|c|c|c|c|}
\hline Response & Predictor & Slope & p-value & SE & $\begin{array}{l}\mathbf{R}^{2} \text { for } \\
\text { the full } \\
\text { model } \\
\end{array}$ & MSE full & $\begin{array}{l}\text { MSE } \\
\text { partial }\end{array}$ & $\begin{array}{l}\text { Sample size } \\
\text { (number of } \\
\text { plots) }\end{array}$ \\
\hline \multirow{6}{*}{$\begin{array}{l}\text { Total } \\
\text { richness }\end{array}$} & Landscape age & -0.08 & $<<0.001$ & 0.02 & 0.28 & 0.72 & 0.99 & 4414 \\
\hline & Precipitation & 0.15 & 0.03 & 0.07 & & & & \\
\hline & Precipitation^2 & -0.46 & $<<0.001$ & 0.06 & & & 0.89 & \\
\hline & Temperature & 0.97 & $<<0.001$ & 0.07 & & & & \\
\hline & Temperature $^{\wedge} 2$ & -0.93 & $<<0.001$ & 0.06 & & & 0.97 & \\
\hline & Area & 0.33 & $<<0.001$ & 0.01 & & & 0.82 & \\
\hline \multirow{5}{*}{$\begin{array}{l}\text { Vascular } \\
\text { richness }\end{array}$} & Landscape age & 0.06 & $<<0.001$ & 0.01 & 0.28 & 0.77 & 0.93 & 6192 \\
\hline & Precipitation & -0.18 & $<<0.001$ & 0.01 & & & 0.99 & \\
\hline & Temperature & 0.83 & $<<0.001$ & 0.06 & & & & \\
\hline & Temperature $^{\wedge} 2$ & -0.62 & $<<0.001$ & 0.05 & & & 0.91 & \\
\hline & Area & 0.36 & $<<0.001$ & 0.01 & & & 0.76 & \\
\hline \multirow{6}{*}{$\begin{array}{l}\text { Bryophyte } \\
\text { richness }\end{array}$} & Landscape age & 0.07 & 0.002 & 0.02 & 0.13 & 0.87 & 0.98 & 4427 \\
\hline & Precipitation & 0.59 & $<<0.001$ & 0.08 & & & & \\
\hline & Precipitation^2 & -0.78 & $<<0.001$ & 0.07 & & & 0.92 & \\
\hline & Temperature & 0.53 & $<<0.001$ & 0.07 & & & & \\
\hline & Temperature $^{\wedge} 2$ & -0.65 & $<<0.001$ & 0.07 & & & 0.99 & \\
\hline & Area & 0.13 & $<<0.001$ & 0.02 & & & 0.97 & \\
\hline \multirow{6}{*}{$\begin{array}{l}\text { Lichen } \\
\text { richness }\end{array}$} & Landscape age & -0.19 & $<<0.001$ & 0.02 & 0.23 & 0.77 & 1.00 & 4431 \\
\hline & Precipitation & 0.30 & $<<0.001$ & 0.07 & & & & \\
\hline & Precipitation^2 & -0.56 & $<<0.001$ & 0.06 & & & 0.94 & \\
\hline & Temperature & 1.10 & $<<0.001$ & 0.07 & & & & \\
\hline & Temperature $^{\wedge} 2$ & -1.20 & $<<0.001$ & 0.06 & & & 0.95 & \\
\hline & Area & 0.29 & $<<0.001$ & 0.01 & & & 0.90 & \\
\hline \multirow{3}{*}{$\begin{array}{l}\text { Genetic } \\
\text { diversity }\end{array}$} & Landscape age & 0.85 & $<<0.001$ & 0.008 & 0.80 & 0.20 & 0.22 & 7509 \\
\hline & Temperature & 0.48 & $<<0.001$ & 0.03 & & & & \\
\hline & Temperature $^{\wedge} 2$ & -0.18 & $<<0.001$ & 0.02 & & & 0.74 & \\
\hline
\end{tabular}




\section{Appendix S6 Test of predictive ability}

To test the predictive ability of our models, we used a geographically independent validation approach defining independent training and testing datasets for all models. Calibration of the models was carried out with data from eastern North America and western Eurasia (see figure below). These models were then used to predict richness in the other half of the Arctic (western North America and eastern Eurasia). This was done at the plot scale for total species richness, vascular plants, bryophytes and lichens as well as at the regional scale and for genetic diversity. To see how well the models predicted richness in the testing area, we computed Pearson correlations between predicted and observed richness. At the plot scale the correlations were for total 0.44 , for vascular plants 0.64 , for bryophytes -0.02 and for lichens 0.25 . For regional richness of vascular plants the correlation was 0.75 and for genetic diversity it was 0.83 .

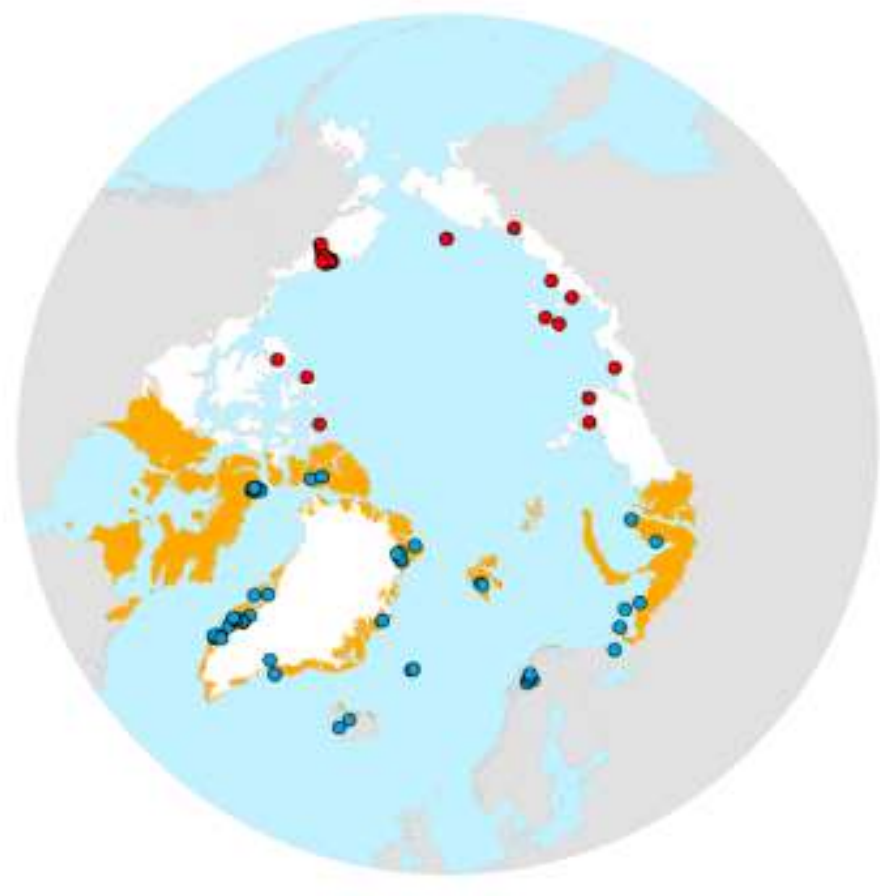

Figure S6: Map of the Arctic and surrounding areas. Orange areas show the regions (10 CAVM regions) used for training models for regional species richness and genetic diversity whereas the white areas show test regions (11 CAVM regions). At the plot scale the same geographic boundaries were used to choose points for training and testing. This resulted in 4945 plots for training (79.6\%, blue dots) and 1270 plots for testing (20.4\% red dots). 


\section{Appendix S7 Results of generalised linear models}

Table S7. Summary of generalised linear models (glm) of plot species richness (total, vascular, bryophytes and lichens) as a function of landscape age, plot size (area), temperature and precipitation as well as genetic diversity as function of landscape age and temperature. The variable landscape age was published in Raynolds and Walker (2009). For temperature and precipitation we used the Bioclim variables mean temperature of the warmest quarter and annual precipitation from WorldClim (Hijmans et al., 2005) (http://www.worldclim.org/). Glm's were fitted using gaussian distribution. Data was scaled to cero mean and unit variance. $\mathrm{R}^{2}$ is calculated as the squared Pearson correlation between predicted and observed values (Kissling \& Carl, 2008). Mean Squared Error (MSE) is presented both for the full model and for models including one variable at a time (Partial MSE)

\begin{tabular}{|c|c|c|c|c|c|c|c|c|}
\hline Response & Predictor & Slope & p-value & SE & $\begin{array}{l}R^{2} \text { for } \\
\text { the full } \\
\text { model }\end{array}$ & MSE full & $\begin{array}{l}\text { MSE } \\
\text { partial }\end{array}$ & $\begin{array}{l}\text { Sample size } \\
\text { (number of } \\
\text { plots) }\end{array}$ \\
\hline \multirow{6}{*}{$\begin{array}{l}\text { Total } \\
\text { richness }\end{array}$} & Landscape age & -0.08 & $<<0.001$ & 0.02 & 0.28 & 0.72 & 0.99 & 4414 \\
\hline & Precipitation & 0.15 & 0.03 & 0.07 & & & & \\
\hline & Precipitation^2 & -0.46 & $<<0.001$ & 0.06 & & & 0.89 & \\
\hline & Temperature & 0.97 & $<<0.001$ & 0.07 & & & & \\
\hline & Temperature $^{\wedge} 2$ & -0.93 & $<<0.001$ & 0.06 & & & 0.97 & \\
\hline & Area & 0.33 & $<<0.001$ & 0.01 & & & 0.82 & \\
\hline \multirow{5}{*}{$\begin{array}{l}\text { Vascular } \\
\text { richness }\end{array}$} & Landscape age & 0.06 & $<<0.001$ & 0.01 & 0.28 & 0.77 & 0.93 & 6192 \\
\hline & Precipitation & -0.18 & $<<0.001$ & 0.01 & & & 0.99 & \\
\hline & Temperature & 0.83 & $<<0.001$ & 0.06 & & & & \\
\hline & Temperature $^{\wedge} 2$ & -0.62 & $<<0.001$ & 0.05 & & & 0.91 & \\
\hline & Area & 0.36 & $<<0.001$ & 0.01 & & & 0.76 & \\
\hline \multirow{6}{*}{$\begin{array}{l}\text { Bryophyte } \\
\text { richness }\end{array}$} & Landscape age & 0.07 & 0.002 & 0.02 & 0.13 & 0.87 & 0.98 & 4427 \\
\hline & Precipitation & 0.59 & $<<0.001$ & 0.08 & & & & \\
\hline & Precipitation^2 & -0.78 & $<<0.001$ & 0.07 & & & 0.92 & \\
\hline & Temperature & 0.53 & $<<0.001$ & 0.07 & & & & \\
\hline & Temperature $^{\wedge} 2$ & -0.65 & $<<0.001$ & 0.07 & & & 0.99 & \\
\hline & Area & 0.13 & $<<0.001$ & 0.02 & & & 0.97 & \\
\hline \multirow{6}{*}{$\begin{array}{l}\text { Lichen } \\
\text { richness }\end{array}$} & Landscape age & -0.19 & $<<0.001$ & 0.02 & 0.23 & 0.77 & 1.00 & 4431 \\
\hline & Precipitation & 0.30 & $<<0.001$ & 0.07 & & & & \\
\hline & Precipitation^^2 & -0.56 & $<<0.001$ & 0.06 & & & 0.94 & \\
\hline & Temperature & 1.10 & $<<0.001$ & 0.07 & & & & \\
\hline & Temperature ${ }^{\wedge} 2$ & -1.20 & $<<0.001$ & 0.06 & & & 0.95 & \\
\hline & Area & 0.29 & $<<0.001$ & 0.01 & & & 0.90 & \\
\hline \multirow{3}{*}{$\begin{array}{l}\text { Genetic } \\
\text { diversity }\end{array}$} & Landscape age & 0.33 & $<<0.001$ & 0.009 & 0.53 & 0.47 & 0.70 & 7509 \\
\hline & Temperature & 0.45 & $<<0.001$ & 0.009 & & & & \\
\hline & Temperature^ ${ }^{\wedge}$ & 0.17 & $<<0.001$ & 0.009 & & & 0.56 & \\
\hline
\end{tabular}




\section{Appendix S8}

Plots of interpolated genetic diversity against individual genetic diversity of the 24 species. Regression lines indicate significant relationships $(\mathrm{p}<0.05)$.
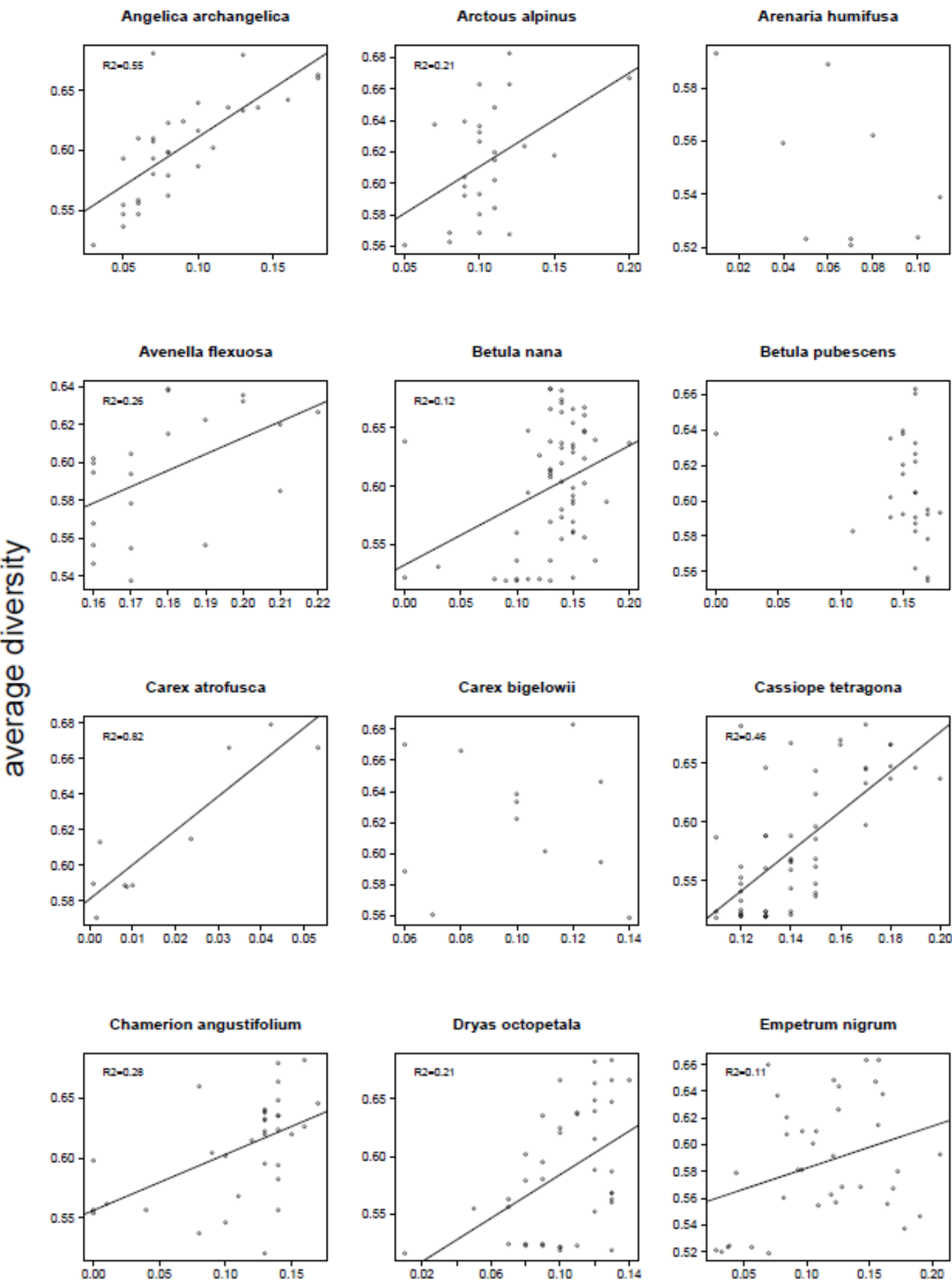

Individual diversity
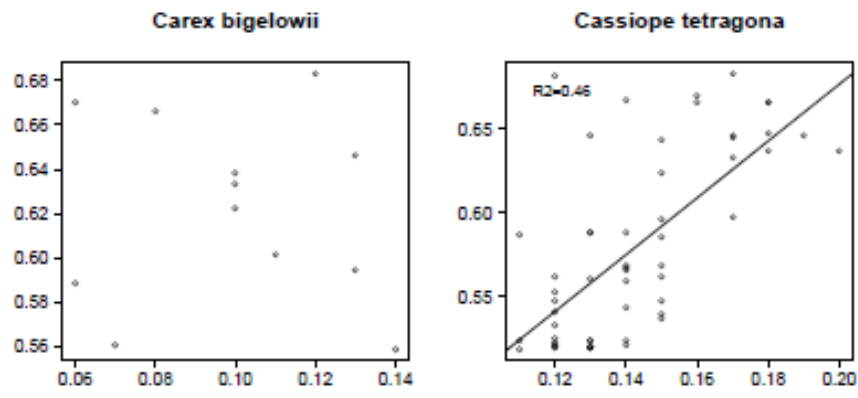

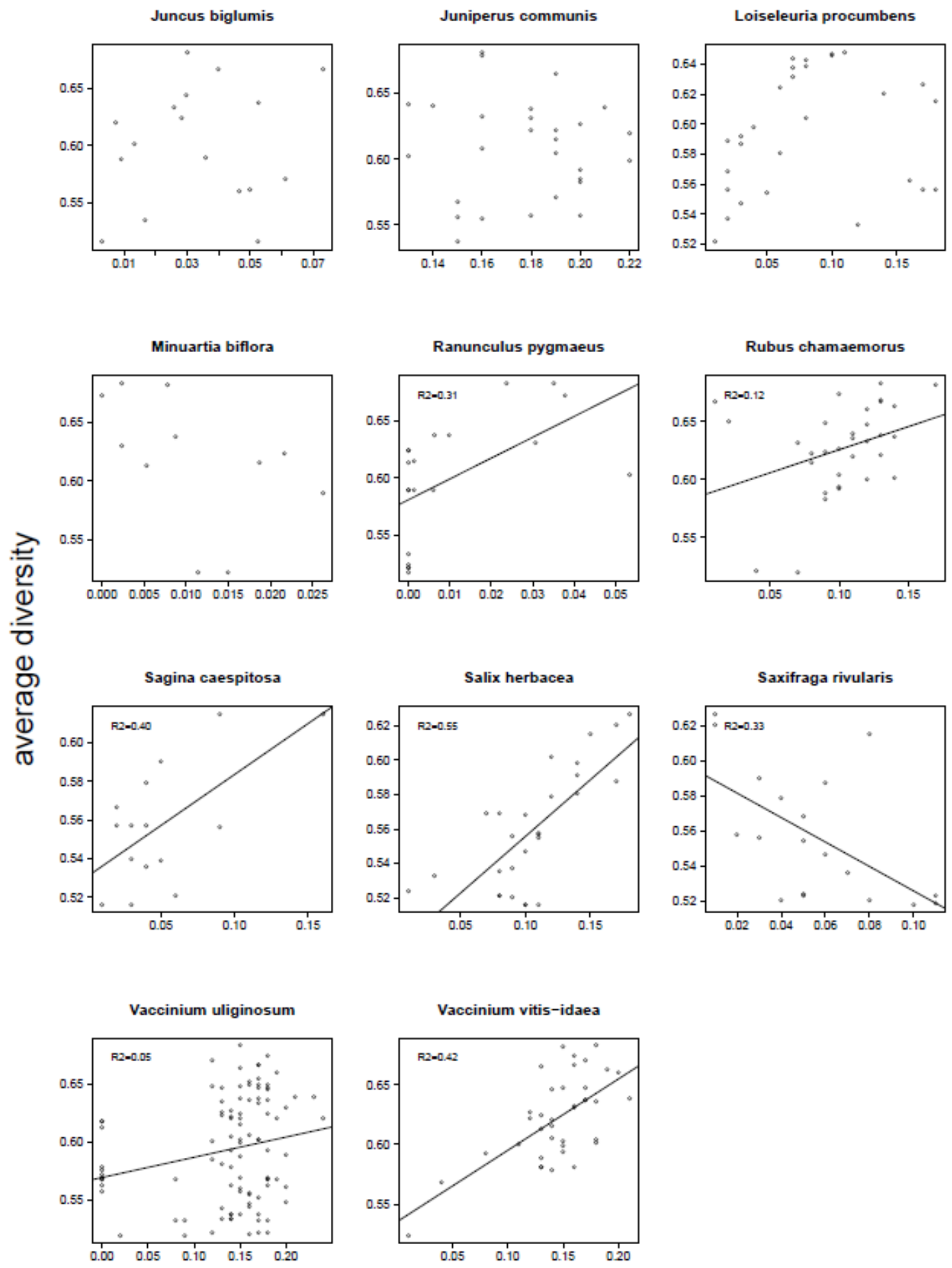

Individual diversity 
Appendix S9 Box-and-whisker plot of the relationship between mean species richness per plot and landscape age.
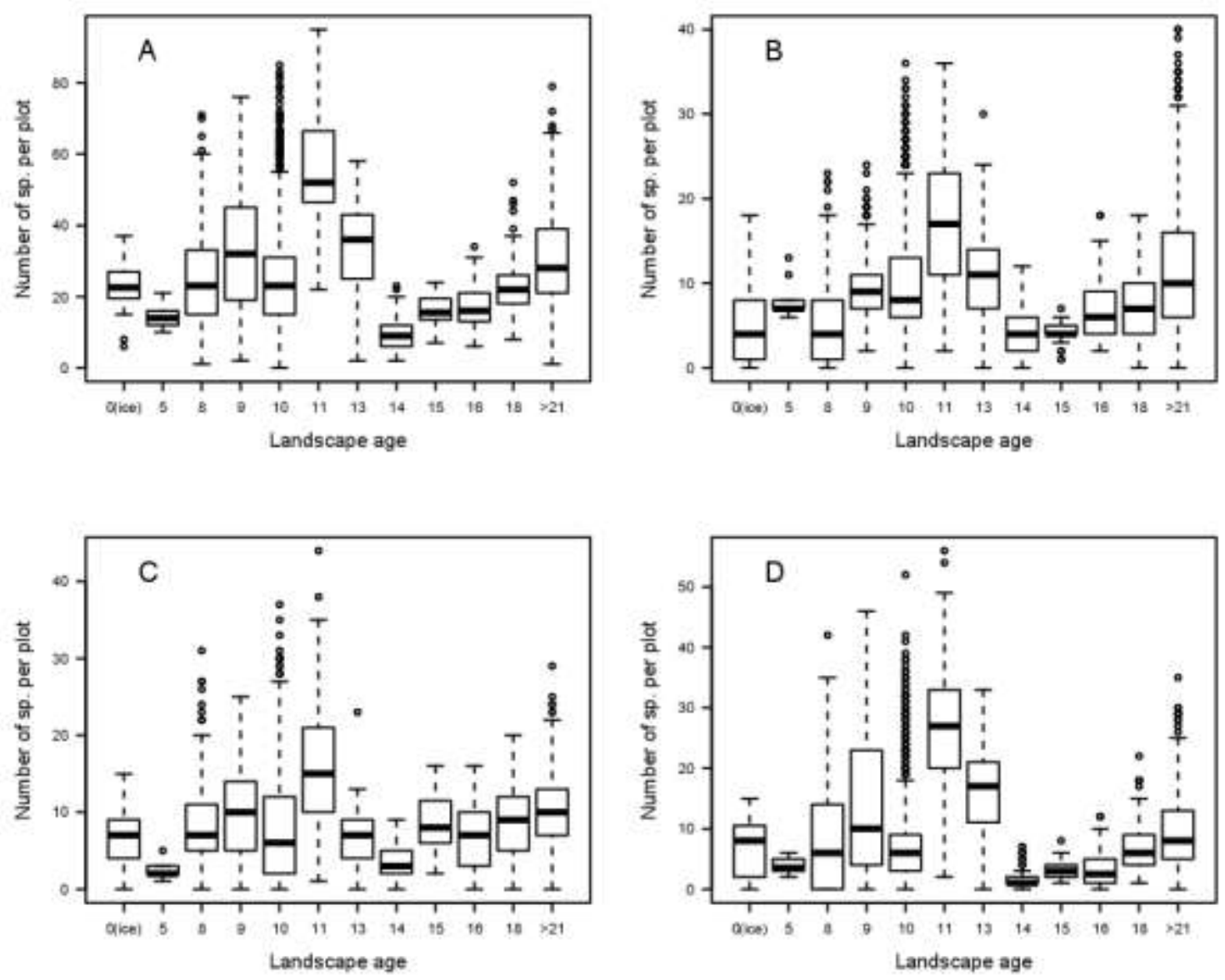

Figure S9. Mean number of species per plot within categories of landscape age for A: total species richness, B: vascular plants, C: bryophytes and D: terricollous lichens.

There is no obvious pattern between mean number of species per plot within the different categories of landscape age. 


\section{Appendix S10 Correlation of plot species richness with regional species richness}

To see whether plot species richness of vascular plants, bryophytes and lichens correlate with regional species richness of vascular plants we used a simultaneous autoregressive model (SAR $\mathrm{err})$ with regional richness as response variable and plot species richness and size of the plot (area) as explanatory variables.

Table S10. Summary of simultaneous autoregressive $\left(\mathrm{SAR}_{\text {err }}\right)$ models of regional species richness of vascular plants as a function of plot species richness and are. All variables were scaled to cero mean and unit variance previous to analyses. $\mathrm{R}^{2}$ is calculated as the squared Pearson correlation between predicted and observed values (Kissling \& Carl, 2008).

\begin{tabular}{|c|c|c|c|c|c|}
\hline Response & Predictor & Slope & p-value & $\begin{array}{l}\mathbf{R}^{2} \text { for the full } \\
\text { model }\end{array}$ & $\begin{array}{l}\begin{array}{l}\text { Sample } \\
\text { size } \\
\text { (number of } \\
\text { plots) }\end{array} \\
\end{array}$ \\
\hline $\begin{array}{l}\text { Regional richness } \\
\text { of vascular plants }\end{array}$ & $\begin{array}{l}\text { Plot richness (total) } \\
\text { Area }\end{array}$ & $\begin{array}{l}-0.12 \\
0.51\end{array}$ & $\begin{array}{l}0.62 \\
0.10\end{array}$ & 0.29 & 4414 \\
\hline $\begin{array}{l}\text { Regional richness } \\
\text { of vascular plants }\end{array}$ & $\begin{array}{l}\text { Plot richness (vascular) } \\
\text { Area }\end{array}$ & $\begin{array}{l}0.35 \\
0.20\end{array}$ & $\begin{array}{l}0.22 \\
0.44\end{array}$ & 0.32 & 6192 \\
\hline $\begin{array}{l}\text { Regional richness } \\
\text { of vascular plants }\end{array}$ & $\begin{array}{l}\text { Plot richness (bryophytes) } \\
\text { Area }\end{array}$ & $\begin{array}{l}0.07 \\
0.41\end{array}$ & $\begin{array}{l}0.80 \\
0.21\end{array}$ & 0.28 & 4427 \\
\hline $\begin{array}{l}\text { Regional rcichness } \\
\text { of vascular plants }\end{array}$ & $\begin{array}{l}\text { Plot richness (lichen) } \\
\text { Area }\end{array}$ & $\begin{array}{l}-0.36 \\
0.62\end{array}$ & $\begin{array}{l}0.09 \\
0.02\end{array}$ & 0.41 & 4431 \\
\hline
\end{tabular}

Plot species richness was not significantly related to regional richness for any of the groups.

Kissling, W.D. \& Carl, G. (2008) Spatial autocorrelation and the selection of simultaneous autoregressive models. Global Ecology and Biogeography, 17, 59-71. 